Ground-Water Resources Program

\title{
Water-Use Trends in the Desert Southwest-1950-2000
}

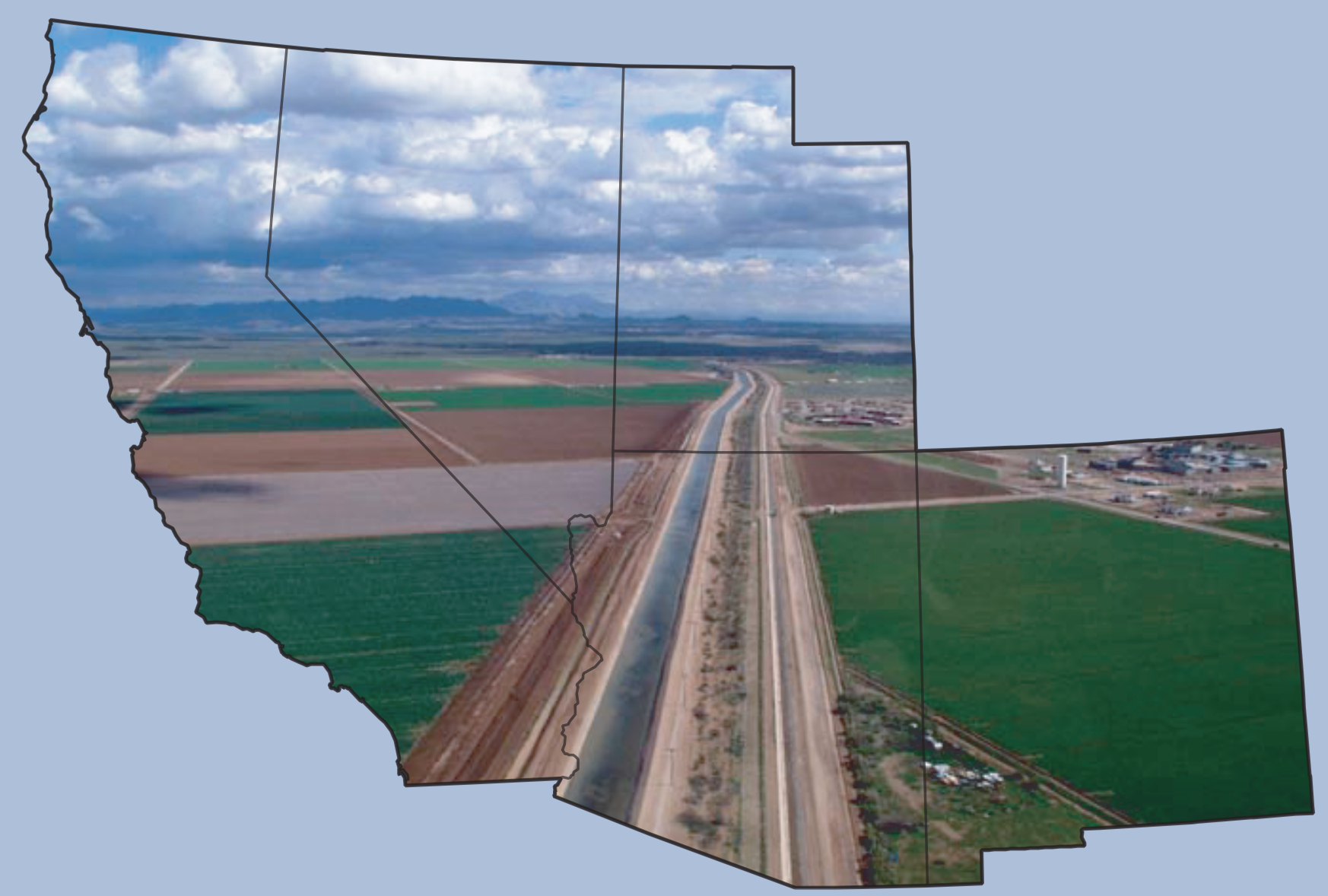

Scientific Investigations Report 2004-5148

U.S. Department of the Interior

U.S. Geological Survey

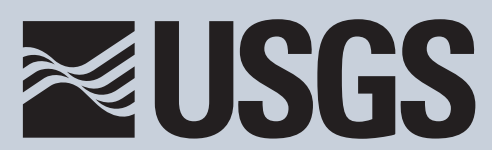



Ground-Water Resources Program

\section{Water-Use Trends in the Desert Southwest-1950-2000}

By A.D. Konieczki and J.A. Heilman

Scientific Investigations Report 2004-5148 


\title{
U.S. Department of the Interior Gale A. Norton, Secretary
}

\author{
U.S. Geological Survey \\ Charles G. Groat, Director
}

\begin{abstract}
For more information about the USGS and its products:
Telephone: 1-888-ASK-USGS

World Wide Web: http://www.usgs.gov/

Any use of trade, product, or firm names in this publication is for descriptive purposes only and does not imply endorsement by the U.S. Government.

Although this report is in the public domain, permission must be secured from the individual copyright owners to reproduce any copyrighted materials contained within this report.
\end{abstract}

\footnotetext{
Suggested citation:

Konieczki, A.D., and Heilman, J.A., 2004, Water-use trends in the desert Southwest-1950-2000: U.S. Geological Survey Scientific Investigations Report 2004-5148, 32 p.
} 


\section{Contents}

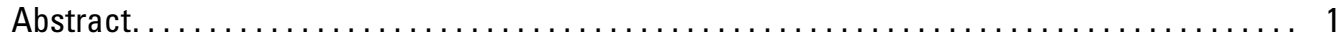

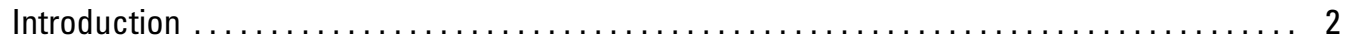

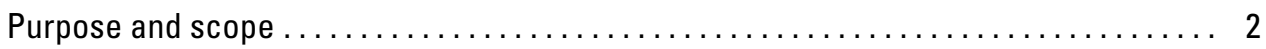

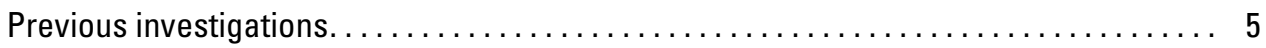

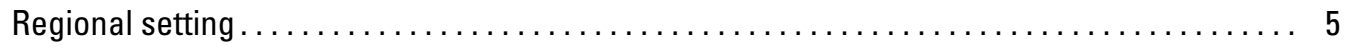

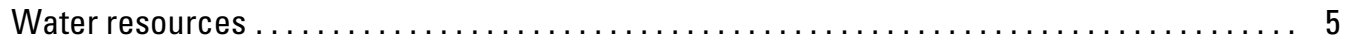

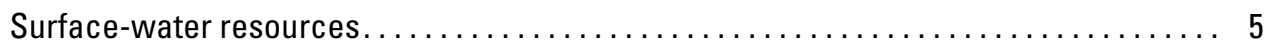

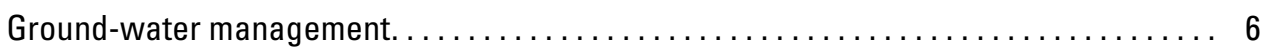

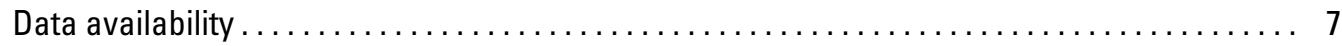

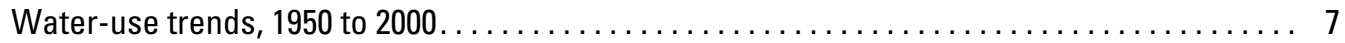

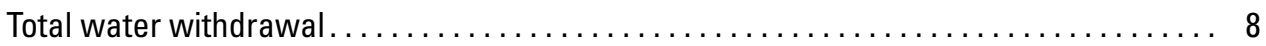

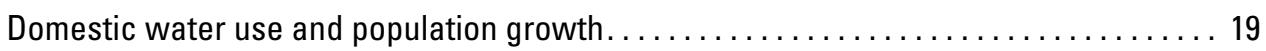

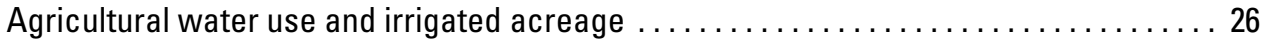

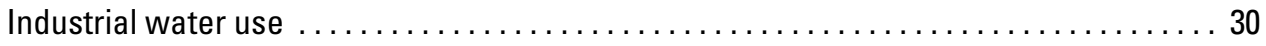

Summary and conclusions. . . . . . . . . . . . . . . 30

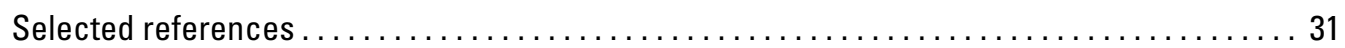




\section{Figures}

1-3. Maps showing:

Figure 1. States, Basin and Range Physiographic Province, and water-resources

regions in the Desert Southwest ............................ 3

Figure 2. Counties in the Basin and Range Physiographic Province .............. 4

Figure 3. Basins identified by each State in the Basin and Range Physiographic

Province that require ground-water management or monitoring $\ldots \ldots \ldots \ldots \ldots 6$

4-13. Graphs showing:

Figure 4. Ground-water and surface-water withdrawal and percentage of total withdrawal that is ground water and surface water, 1950-2000

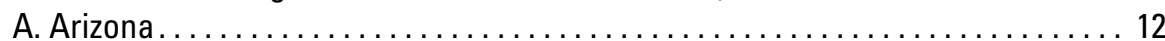

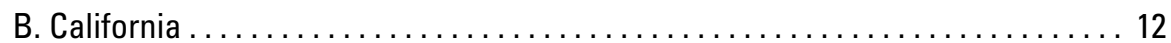

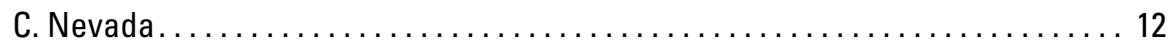

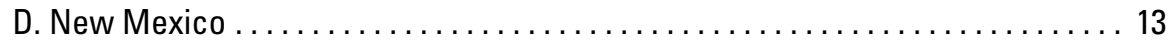
E. Utah.............................................. 13

Figure 5. Ground-water withdrawal in Arizona and the Upper Santa Cruz Basin

and annual and mean-annual precipitation at the National Weather

Service rain gage in Tucson, Arizona $\ldots \ldots \ldots \ldots \ldots \ldots \ldots \ldots \ldots \ldots \ldots \ldots$

Figure 6. Ground-water withdrawal in Utah and Salt Lake Valley and annual and mean-annual precipitation at the National Weather Service rain gage in Salt Lake City, Utah ............................ 14

Figure 7. Population and projected population for Arizona, Utah, Nevada, New Mexico, and California, 1950-2025 ........................ 19

Figure 8. Population for selected counties within the Basin and Range

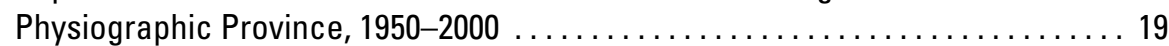

Figure 9. Population, and ground-water, surface-water, and total withdrawal for domestic water use, 1950-2000
A. Arizona . . . . . . . . . . . . . . . . . . . . . . . . . . . . 20

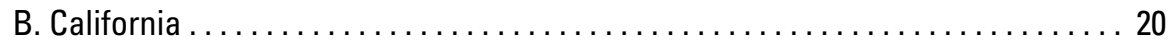

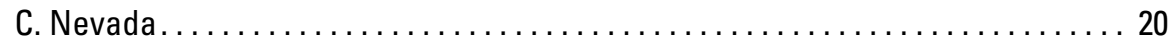

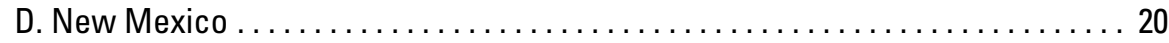
E. Utah. . . . . . . . . . . . . . . . . . . . . . . . . . . . . . 20

Figure 10. Percentage of ground-water and surface-water withdrawal for agricultural and domestic water uses, 1950-2000:
A. Arizona.
B. California $\ldots \ldots \ldots \ldots \ldots \ldots \ldots \ldots \ldots \ldots \ldots \ldots \ldots \ldots \ldots \ldots \ldots \ldots \ldots \ldots \ldots$

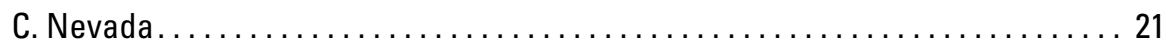
D. New Mexico ..................................... 21
E. Utah. . . . . . . . . . . . . . . . . . . . . . . . . . . . . . 21

Figure 11. Per-capita use of public-supply water in Arizona, California, Nevada,

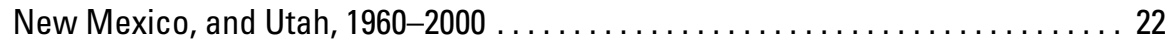

Figure 12. Total withdrawal, and ground-water, surface-water, and total withdrawal for agricultural uses, and irrigated acreage, 1950-2000:

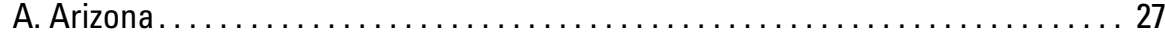

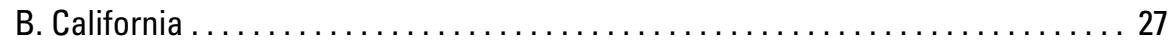

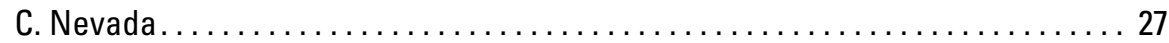

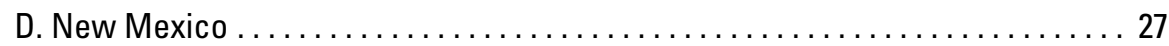

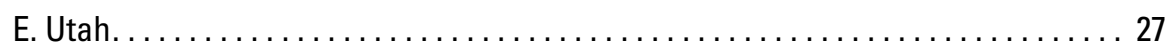

Figure 13. Crop-application rates in Arizona, California, Nevada, New Mexico,

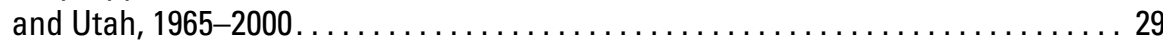




\section{Tables}

Table 1 Availability of water-use and related data for the Desert Southwest,

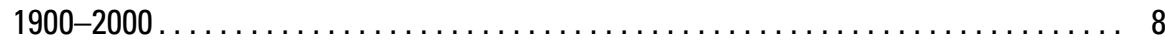

Table 2. Freshwater withdrawal by water-use category and source in Arizona, California, Nevada, New Mexico, and Utah, 1950-2000................ 9

Table 3. Freshwater withdrawal by water-use category and source in the California, Great Basin, lower Colorado, and Rio Grande water-resources regions, 1965-1995 10

Table 4. Freshwater withdrawal by source in counties in the Basin and Range

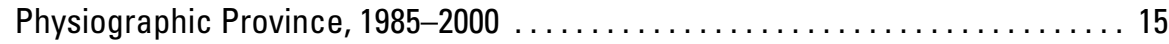

Table 5. Irrigated acreage in counties in the Basin and Range Physiographic

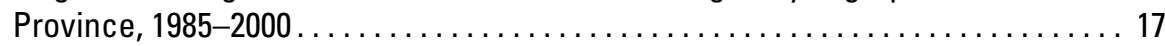

Table 6. Populations of Arizona, California, Nevada, New Mexico, and

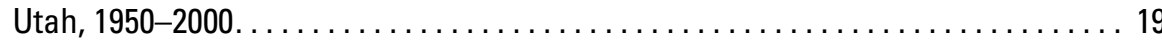

Table 7. Public supply per-capita use in Arizona, California, Nevada, New Mexico,

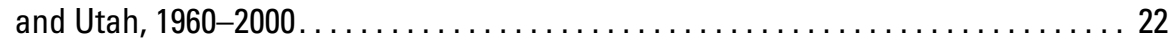

Table 8. Freshwater withdrawal by water-use category in counties in the Basin and Range Physiographic Province, $1985-2000 \ldots \ldots \ldots \ldots \ldots \ldots \ldots 23$

Table 9. Public supply per-capita use in counties in the Basin and Range

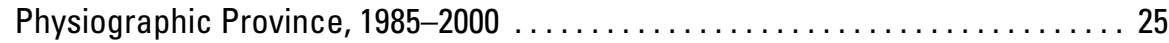

Table 10. Percentage of State populations represented by counties in the Basin

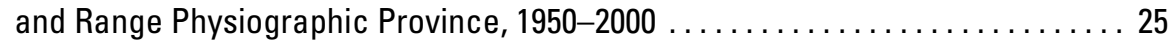

Table 11. Population in the California, Great Basin, lower Colorado, and

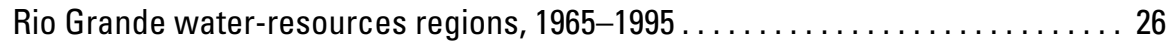

Table 12. Irrigated acreage in Arizona, California, Nevada, New Mexico, and

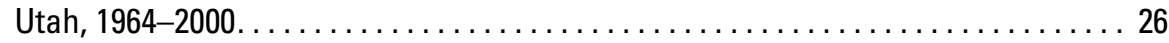

Table 13. Irrigated acreage in the lower Colorado, Great Basin, California, and Rio Grande water-resources regions, $1965-1995 \ldots \ldots \ldots \ldots \ldots \ldots \ldots 29$

Table 14. Crop-application rates in Arizona, California, Nevada, New Mexico, and Utah, 1965-2000.

\section{Conversion Factors}

\begin{tabular}{lcl}
\hline Multiply & \multicolumn{1}{c}{ By } & To obtain \\
\hline inch (in) & 2.54 & centimeter \\
mile (mi) & 1.609 & kilometer \\
acre & 0.004047 & square kilometer \\
square mile $\left(\mathrm{mi}^{2}\right)$ & 259.0 & hectare \\
square mile $\left(\mathrm{mi}^{2}\right)$ & 2.590 & square kilometer \\
acre-foot $(\mathrm{acre}-\mathrm{ft})$ & 1,233 & cubic meter \\
acre-foot (acre-ft) & 0.001233 & cubic hectometer \\
gallon per day $(\mathrm{gal} / \mathrm{d})$ & 0.003785 & cubic meter per day \\
\hline
\end{tabular}

Temperature in degrees Fahrenheit $\left({ }^{\circ} \mathrm{F}\right)$ may be converted to degrees Celsius $\left({ }^{\circ} \mathrm{C}\right)$ as follows: ${ }^{\circ} \mathrm{C}=\left({ }^{0} \mathrm{~F}-32\right) / 1.8$. 



\title{
Water-Use Trends in the Desert Southwest—1950-2000
}

\author{
By A.D. Konieczki and J.A. Heilman
}

\section{Abstract}

The population in the Desert Southwest is among the fastest growing in the country. In this area, groundwater supplies have been developed, surface-water resources have been fully appropriated, and conservation and conjunctive water-use measures are being used to meet water-resource needs. Complex networks of water-distribution systems have been developed to deliver surface-water supplies, and interstate agreements, such as the Colorado River Compact of 1922, help manage the distribution of water among many States in the Western United States, including Arizona, California, Nevada, New Mexico, and Utah.

The Colorado River, which lies on the borders of Arizona, California, and Nevada, plays an important role in supplying water to the Southwest. Water from the Colorado River is used to irrigate extensive farmland in the southern California deserts and is delivered to southern and central Arizona through the Central Arizona Project canal for domestic and agricultural uses. It is also the source of much of the water used for domestic purposes in southern Nevada.

Estimated water-withdrawal and related data were compiled from various sources to identify trends in Arizona, California, Nevada, New Mexico, and Utah. More water is used for agriculture than domestic and industrial use in these five States. From 1950 to 2000, however, the percentage increase in withdrawal for domestic water use exceeded that for agricultural use.

The estimated amount of water withdrawn for domestic, agricultural, and industrial purposes in Arizona, California, Nevada, New Mexico, and Utah increased 58 percent, from 39.6 to 62.8 million acre-feet, from 1950 to 2000. During this period withdrawals for domestic water use, which included self-supplied domestic and public supply (all deliveries to residential, commercial, and some industrial users), increased 410 percent from 2.0 million to 10.2 million acre-feet and the population in these five Southwestern States increased 250 percent. From 1965 to 2000, water withdrawals for agriculture, which were primarily for irrigation of crops and livestock uses, increased 14 percent in the five States, from 44.0 to 50.2 million acre-feet, while irrigated acreage increased 12 percent from 12.6 to 14.1 million acres.

Water-use trends in the Southwest are dominated by water use in California where crop acreage is more than twice as large as the combined crop acreages in Arizona, Nevada, New Mexico, and Utah, and the population in 2000 was more than three times larger than the combined population of these States.

Withdrawals for agriculture in California accounted for 62 percent of the water withdrawals for agriculture in the five States in 1950 and 68 percent in 2000. Water withdrawals for domestic-water use in California declined from 82 percent of the total domestic-water withdrawals in all five States in 1950 to 70 percent in 2000, indicating that the need for domestic withdrawals increased more in Arizona, Nevada, New Mexico, and Utah combined than in California.

The population of California is larger than the combined population of Arizona, New Mexico, Nevada, and Utah, but the combined population of these smaller States grew faster than the population of California. From 1950 to 2000 the California population increased 220 percent, but the combined population of the four 
other States increased 390 percent. From 1960 to 2000, public supply per-capita use increased in Arizona, New Mexico, and California, and decreased in Nevada and Utah.

Crop-application rates (water withdrawal for irrigation of crops divided by the irrigated crop acreage) from 1965 to 2000 ranged from 2.32 acrefeet per acre in Utah in 1975 to 6.21 acre-feet per acre in Arizona in 2000. More water is used per acre of irrigated land in Arizona than in the other four States. This could be due to several reasons, including differences in climate, conveyance losses, length of growing season, and type of crops grown.

Trends in water withdrawals for industrial use are difficult to identify because of differences in data reporting from year to year. From 1950 to 2000, withdrawal for industrial use in the five States was generally less than 6 percent of the total withdrawal. Withdrawal for industrial use was less than 4 percent of the total withdrawal in Arizona, except in 1990; industrial withdrawal was less than 6 percent in California and less than 7 percent in Nevada, New Mexico, and Utah, except in 1980 when in Utah it was almost 12 percent of the total withdrawal.

From 1950 to 2000, ground-water withdrawals increased 324 percent in Nevada, 147 percent in New Mexico, 208 percent in Utah, and 52 percent in California. Ground-water withdrawal decreased 15 percent in Arizona. For all five States, groundwater withdrawals increased 62 percent.

\section{INTRODUCTION}

Information on trends in water use and major wateruse categories are needed to evaluate current and potential future water needs. The possible effect on water resources can be determined by identifying the locations and sources of water that was used. This is of particular importance at a regional scale in the Southwest. Comparisons of water use, water-use trends, and sources of water among the Southwestern States could assist in the distribution management of limited water resources.

The population in the Southwest is among the fastest growing in the United States. The region could once be described as vast, open, and undeveloped, with isolated population clusters where water was readily available. In the last few decades, however, the populated areas have expanded becoming large metropolitan areas, and development has not always occurred where water is readily available. Large areas of the Southwest remain undeveloped, primarily because publicly owned land is extensive. Federal, State, city, and county land ownerships are limiting factors in land development, and water availability may be another. Development of farmland in valleys where water is available is a typical pattern in the Southwest. Recent population growth in the Southwest has affected land use such that some undeveloped desert land has been converted in the expansion of suburbs and construction of shopping malls, and some irrigated land is fallow or has been urbanized.

\section{Purpose and Scope}

Compilation of existing water-use and related data is part of the Southwest Ground-Water Resources project that is supported by the Ground-Water Resources Program of the U.S. Geological Survey (USGS) Office of Ground Water. The project area comprises the alluvial basins in the Basin and Range Physiographic Province as defined by Fenneman (1931) in southern California, southern Arizona, Nevada, western Utah, and the Rio Grande drainage in New Mexico; however, data and analysis for this report are presented primarily for the entire States because the spatial and temporal availability of water-use and other related data are mainly reported by State, and separation of data by basin was not possible (fig. 1). Discussion also includes water-use trends of the 58 counties and 4 water-resources regions within the alluvial basins in the Basin and Range Physiographic Province and the Rio Grande Basin in New Mexico for periods of available data (figs. 1 and 2).

Data from 1950 to 2000 were compiled and examined to identify changes over time in ground-water and surface-water withdrawals for agricultural, domestic, and self-supplied industrial water uses for the States, counties, and water-resources regions.

Withdrawals for agricultural use include water used for crop irrigation and, when reported, for livestock use. Withdrawals for domestic use include reported public water supply as well as self-supplied domestic use. Withdrawals for industrial water use include selfsupplied water used for mining, thermoelectric, and other general industrial and commercial purposes. Only fresh ground water and surface water for all offstream uses were compiled. Changes in factors that affect water use, such as population and irrigated acreage, are also discussed. Because the boundaries of the water-resources regions are similar to State boundaries, water-use trends within the water-resources regions are discussed only when they differ from the trends within the States. 
Introduction 3

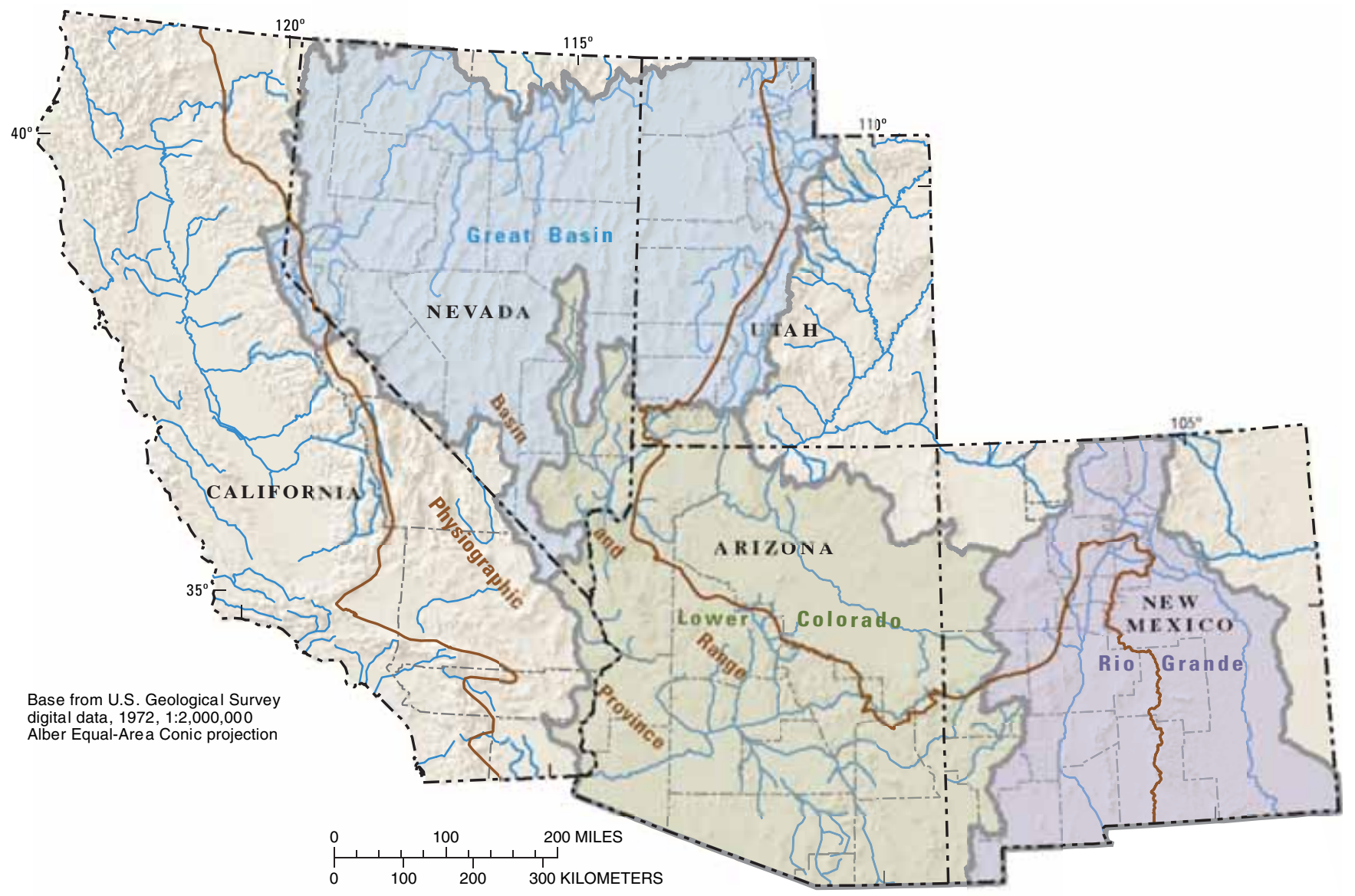

Figure 1. States, Basin and Range Physiographic Province, and water-resources regions in the Desert Southwest. 


\section{Water-Use Trends in the Desert Southwest-1950-2000}

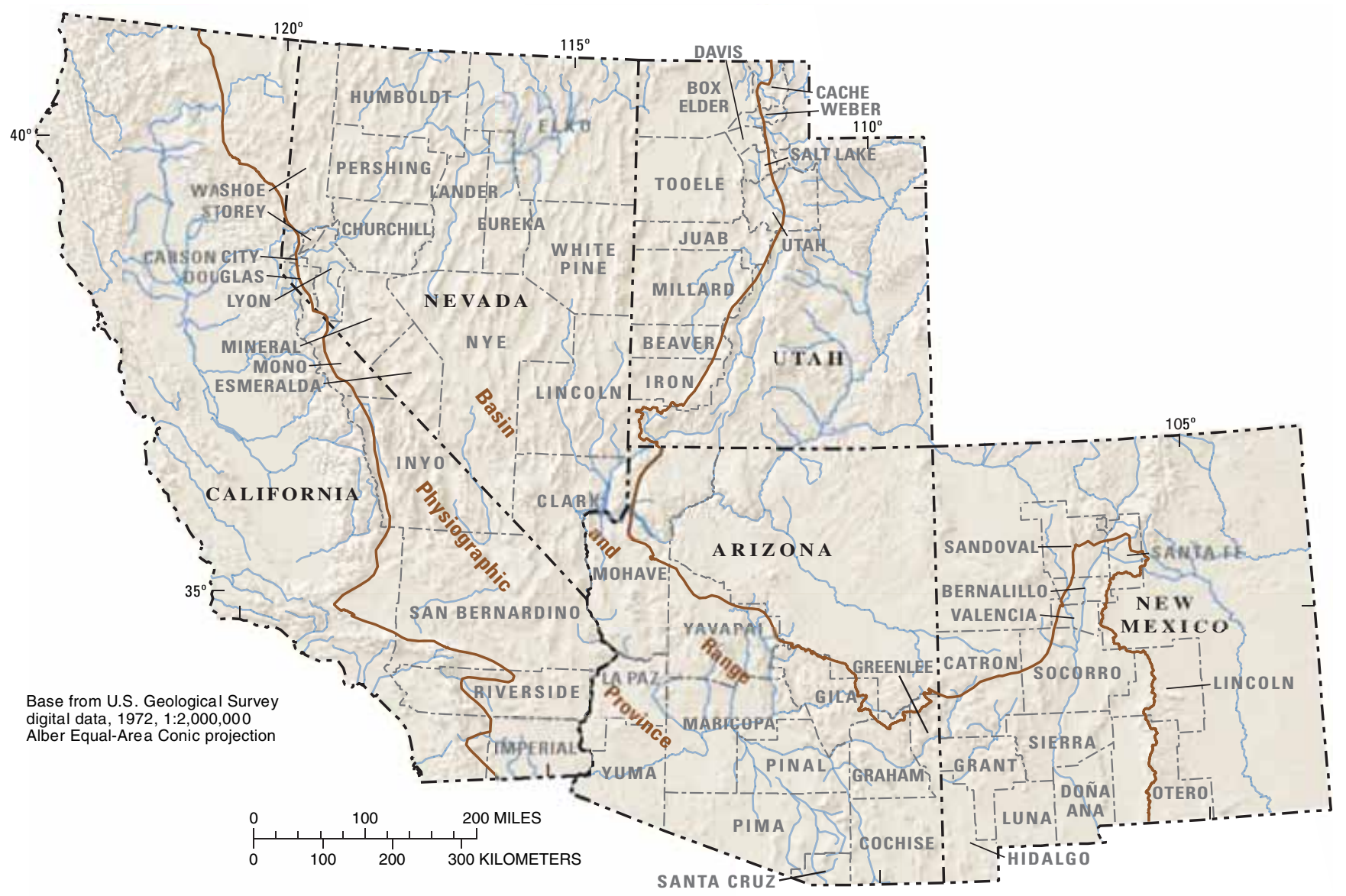

Figure 2. Counties in the Basin and Range Physiographic Province. 


\section{Previous Investigations}

National water-use trends have been noted in previous reports by many authors in the USGS series of reports titled "Estimated Use of Water in the United States." Regional water-use trends for different water-use categories are discussed in Mann and others (1983) and U.S. Geological Survey (1990).

\section{REGIONAL SETTING}

The combined area of California, Arizona, Nevada, New Mexico, and Utah is 583,000 square miles. The five States incorporate five physiographic provinces (Fenneman, 1931). The most prominent province is the Basin and Range Physiographic Province, which comprises about 50 percent of the area. The Basin and Range Physiographic Province encompasses 58 counties in 5 States and 4 water-resources regions. The four waterresources regions are the lower Colorado, California, Great Basin, and Rio Grande (fig. 1).

Precipitation in the five States ranges from about 3 inches per year in the southern California, Arizona, and Nevada deserts to more than 100 inches per year in northern California. The two driest States in the country are Nevada and Utah which have average annual rainfalls of 9 and 13 inches, respectively. Temperatures vary considerably throughout the five States. In the desert areas, temperatures are mild in the winter and hot in the summer, and in the higher elevations and northern part of the area the temperature ranges from cold in the winter to mild in the summer. Most notable in the desert areas of the five States are the diurnal temperature swings, which commonly are about $30^{\circ} \mathrm{F}$.

\section{WATER RESOURCES}

\section{Surface-Water Resources}

Surface water is a fully allocated resource in the arid Southwest. Municipal, State, and Federal laws govern its use and distribution so that the demands of a growing population can be met. There are few major rivers to supply the demand for surface water. Complex networks of water distribution systems have been developed to deliver surface-water supplies where needed, and interstate agreements, such as the Colorado River Compact of 1922, help manage the distribution of water among Arizona, California, Colorado, Nevada, New Mexico, Utah, and Wyoming.
The Colorado River, which lies on the borders of Arizona, California, and Nevada, and flows across the southeastern part of Utah, plays an important role in supplying water to the Southwest. Water from the Colorado River is used to irrigate extensive farmland in the southern California deserts and also is delivered to central and southern Arizona through the Central Arizona Project (CAP) canal for irrigation of crops and publicsupply use. The Colorado River is the source of much of the water used for public supply in southern Nevada. With the exception of the Colorado River drainage, most of the surface water in Utah has been appropriated. The Central Utah Project was designed to deliver water from the Colorado River Basin in eastern Utah to the more populated areas in central Utah. There is also an international agreement between the United States and Mexico for delivery of Colorado River water to Mexico.

The Rio Grande flows from north to south in the western half of New Mexico. Water stored in reservoirs along the Rio Grande is used to irrigate crops in New Mexico and Texas, and like the Colorado River, there is an international agreement for delivery of water to Mexico.

The densest population in the Southwest is in southern California where the climate is generally semiarid to arid and water availability is limited. Some of the water for use in the metropolitan areas in California is transported from northern and central California through the California Aqueduct and from the Colorado River through the Colorado River Aqueduct.

Dams have been built on the major rivers in the Southwest to store water for various purposes, including irrigation, domestic water supply, hydroelectric power, and recreation. Maximum storage capacity in the major reservoirs is about 42 million acre- $\mathrm{ft}$ in Arizona, about 49 million acre-ft in California, about 31 million acre- $\mathrm{ft}$ in Nevada, about 10 million acre-ft in New Mexico, and about 7.5 million acre-ft in Utah. (Ruddy and Hitt, 1990).

Conjunctive use of water-temporary storage of unused surface water in the aquifer to be withdrawn later-is becoming a popular and important method of managing water to help meet the needs of the large and growing population in the Southwest. In California, the Conjunctive Water Management Branch was established to assist local agencies in developing conjunctive wateruse projects, and in Arizona, the legislature established the Underground Water Storage and Recovery program to allow for underground storage of surplus water supplies and withdrawal at a later date as needed. In the Las Vegas, Nev., area, the Southern Nevada Water Authority has recharged more than 242,000 acre-ft of Colorado River water since 1988 (Advisory Committee for Groundwater Management and the Southern Nevada Water Authority, 2002), and in Tucson, Ariz., more than 
15,000 acre-ft of water from the Colorado River is recharged annually to be used at a later time (Tucson Water, 2002).

\section{Ground-Water Management}

The lack of infrastructure to get water where it was needed and the occasionally limited availability of surface water owing to climate conditions contributed to the need to develop ground-water supplies. Development of ground-water supplies also became a necessity as surface-water supplies were allocated. Political, hydrological, and geographical boundaries affect the distribution of water in the Southwest. Each State has statutes that affect the distribution and management of water. Generally, surface water in the West is governed by prior appropriation; the rules that control groundwater allocation, distribution, and management vary from State to State.

In 1980, the Arizona legislature enacted the Arizona Groundwater Management Code (Arizona Department of Water Resources, 2003). The code established three levels of ground-water management. In areas where ground-water withdrawal was the greatest, Active Management Areas (AMAs) were established. In farming areas where withdrawal was not as large, Irrigation Non-Expansion Areas (INAs) were established. There are general conditions of groundwater management for the remainder of the State. Arizona established five AMAs and three INAs in areas in which ground-water overdraft conditions were identified (fig. 3).

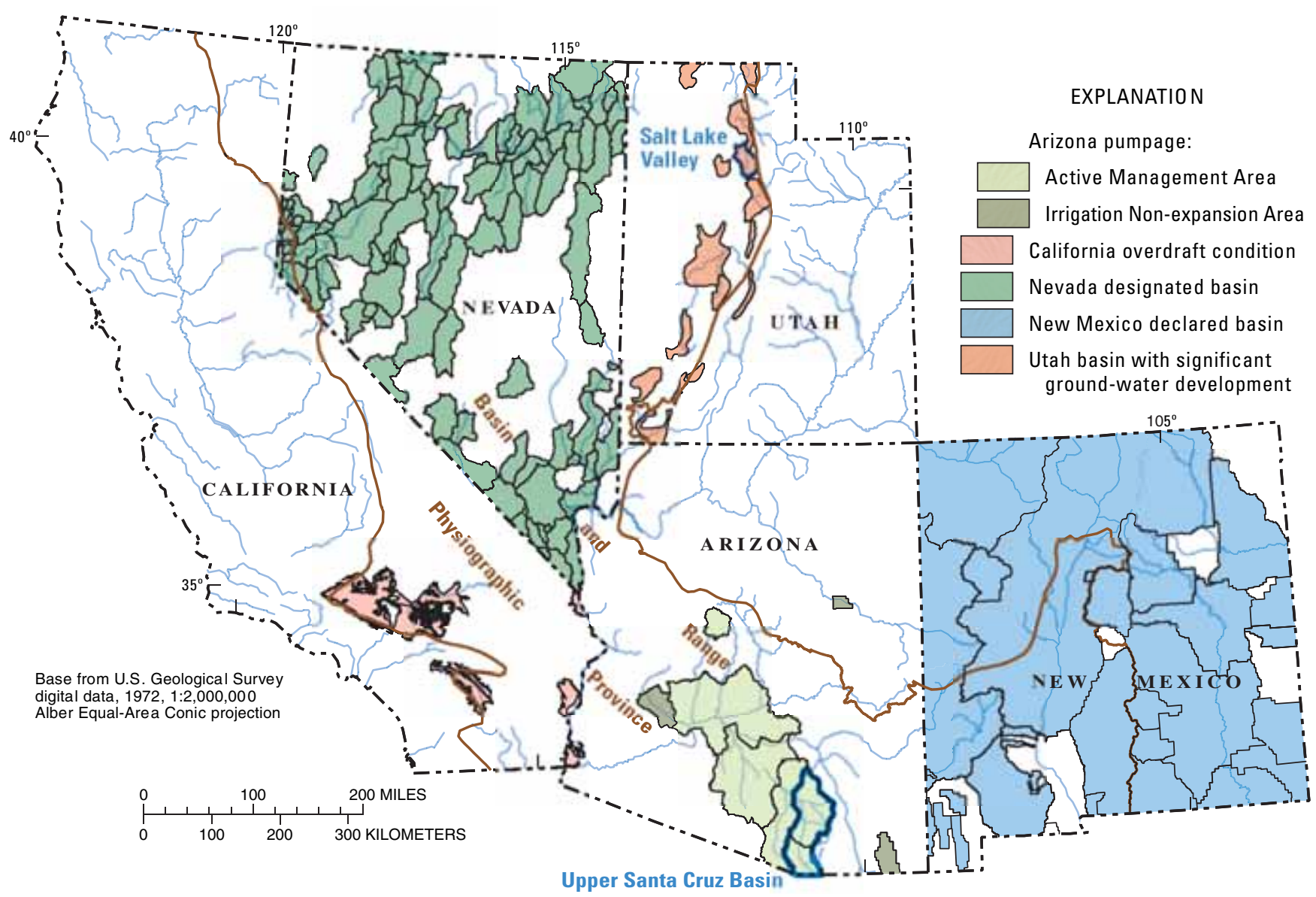

Figure 3. Basins identified by each State in the Basin and Range Physiographic Province that require ground-water management or monitoring. 
California does not have a statewide ground-water management code. Ground-water is managed by local agencies. The California Department of Water Resources, however, monitors and assists local agencies with ground-water issues. In Bulletin 118-80, the California Department of Water Resources (1980) reports that conditions in 42 ground-water basins "indicate overdraft" or provide evidence of "adverse impacts from ground-water overdraft." Furthermore, of those basins adversely affected, 11 are "subject to critical conditions of overdraft." The California Department of Water Resources identifies a basin as "subject to critical conditions of overdraft" when "continuation of present water management practices would probably result in significant adverse overdraft-related environmental, social, or economic impacts" (fig. 3).

In Nevada, the Office of the State Engineer, under the Nevada Department of Conservation and Natural Resources, manages the surface- and ground-water resources. Designated or Administered Groundwater Basins have been identified where "permitted groundwater rights approach or exceed the estimated average annual recharge and the water resources are being depleted or require additional administration." The State Engineer's office in Nevada has designated 115 of 232 basins as needing management of the ground-water resources (fig. 3; Horton, 2001).

In Utah, where the State Engineer administers all water rights, 36 areas of "significant ground-water development" have been identified (fig. 3; Burden and others, 2000). In most of these areas, ground-water withdrawal is less than the estimated recharge.

About 90 percent of the area in New Mexico is in "declared ground-water basins" where appropriation of ground-water resources is by permit only (Wilson and Lucero, 1997). The declared ground-water basin boundaries do not generally have hydrological significance, but are delineated for administrative or ground-water management purposes (fig. 3).

\section{DATA AVAILABILITY}

Although withdrawal data were compiled from many published reports, the main sources of data were the series of USGS Circulars titled "Estimated Use of Water in the United States," published every 5 years since 1950 , and the USGS water-use Web pages (USGS, 2003). Withdrawal data were published by water-use region from 1955 to 1965, but the region boundaries were redefined in 1965, and water-resources region boundaries were used through 1995 . The withdrawal data by region for 1955, 1960, and 1965 were not considered in this report, and withdrawal data by region were not compiled for 2000. Estimated withdrawal data were available by county from the USGS water-use Web pages for 1985 to 1995; data for 2000 were obtained from the USGS State offices.

Estimated withdrawal for both fresh ground water and surface water for all off-stream water-use categories were compiled. The categories for which withdrawal data were available varied during the period 1950 to 2000 . In 1950 and 1955 the rural water-use category included withdrawal for self-supplied domestic and livestock. In 1960, domestic and livestock withdrawals were reported individually in the rural water-use category. Estimated withdrawal data for livestock were not collected in 2000 for many States, including Arizona, Nevada, New Mexico, and Utah. Prior to 1985, estimated mining withdrawals were incorporated into the selfsupplied industrial category, and in 2000, estimated mining withdrawals were not reported in several States, including New Mexico and Nevada.

Additional data were compiled from reports published by the Nevada and New Mexico State Engineers and California and Utah Departments of Water Resources. Ground-water withdrawal data are available for selected basins in Arizona from 1915 to 2000 and from selected areas in Utah from 1963 to present. Population and irrigated-acreage data were obtained from the USGS, the U.S. Census Bureau (U.S. Census Bureau, 2002), and the U.S. Department of Agriculture (USDA, 1999). Availability of the data used for this report is summarized in table 1.

\section{WATER-USE TRENDS, 1950 TO 2000}

Evaluation of water-use trends is assisted by review of estimated withdrawal of fresh ground water and surface water for agricultural, domestic, and industrial use in Arizona, California, Nevada, New Mexico, and Utah. The States were evaluated together and individually. Examination of related water-use data, such as population and irrigated acreage, and factors, such as per-capita water use and crop-application rates, also assist in the analysis of water-use trends. 
8 Water-Use Trends in the Desert Southwest-1950-2000

Table 1. Availability of water-use and related data for the Desert Southwest, 1900-2000

[USGS, U.S. Geological Survey; USDA, U.S. Department of Agriculture. Dashes indicate no data]

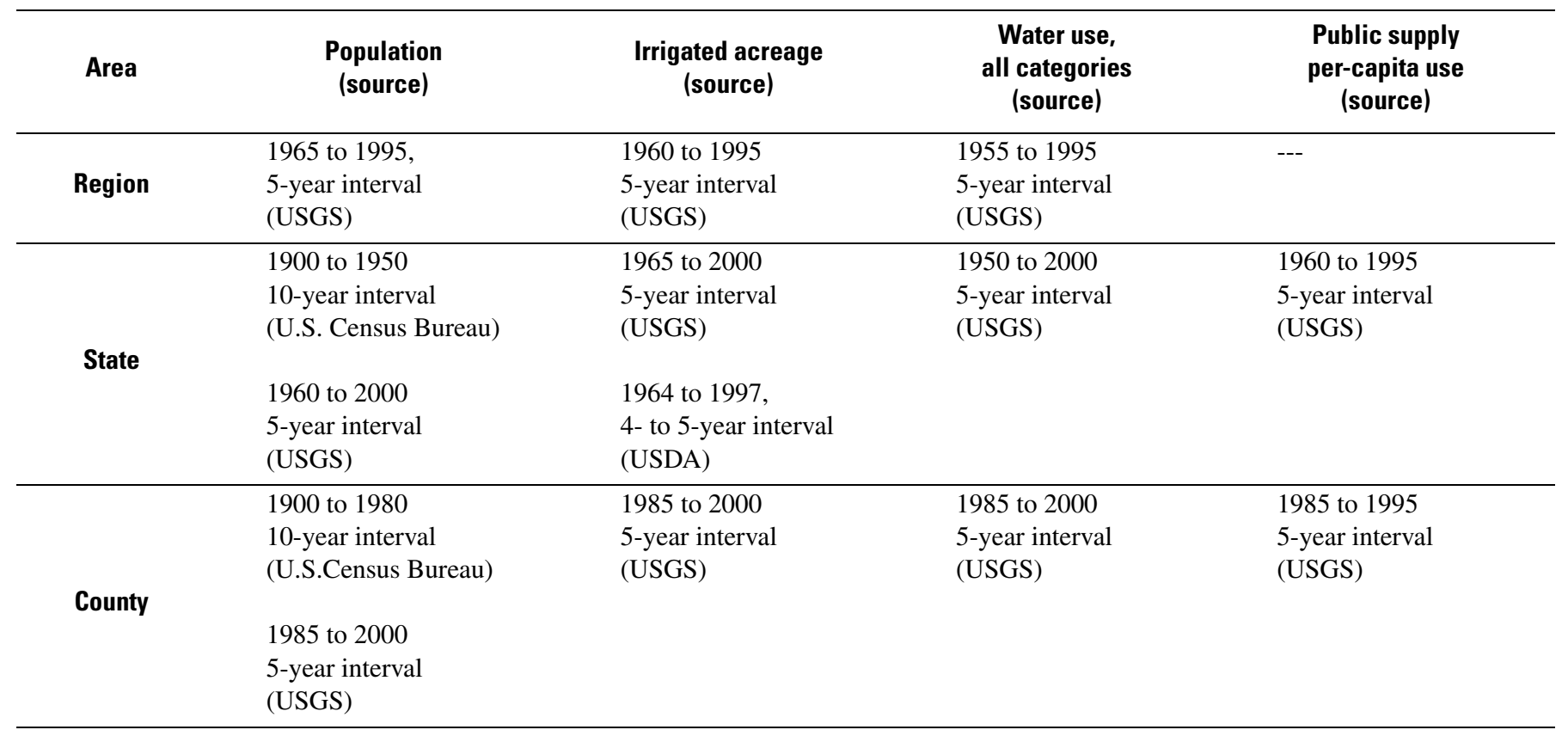

\section{Total Water Withdrawal}

There was an increase in total water withdrawal of 58 percent in the five States from 1950 to 2000 (table 2). This is consistent with the increased need for water for the expanding population, industry, and the associated increased need for agriculture use. Between 1950 and 2000, total withdrawals increased 81 percent in Nevada, 72 percent in California, 46 percent in Utah, and 40 percent in Arizona, and declined 4 percent in New Mexico. Maximum withdrawals from 1950 to 2000 occurred in 1980 in Arizona, California, and New Mexico; in 1985 in Nevada; and in 2000 in Utah.

Water-use trends in the Southwest are dominated by water withdrawals in California. Crop acreage in California is at least twice as large as the combined crop acreages in Arizona, Nevada, New Mexico, and Utah, and in 2000 the population of California was more than three times larger than the combined population of Arizona, Nevada, New Mexico, and Utah.

The ranking of each State's percentages of total withdrawal varied slightly from 1950 to 2000 . Total withdrawal in California represented 63 percent of the total withdrawal for all five States in 1950 and increased to 69 percent in 2000; Arizona declined from 14 to 12 percent; New Mexico represented 10 percent of the total withdrawal in 1950 and declined to 6 percent in 2000; Utah declined from 9 to 8 percent; and Nevada increased from 4 to 5 percent.

Total withdrawal in the four water-resources regions increased 12 percent from 1965 to 1995, and as with the State percentages, the portion of the total withdrawal represented by each region did not change substantially (table 3). From 1965 to 1995, withdrawal increased 21 percent in the lower Colorado water-resources region, 14 percent in California, and 12 percent in the Great Basin, and decreased 6 percent in the Rio Grande waterresources region.

Ground-water and surface-water withdrawals increased 62 and 59 percent, respectively, from 1950 to 2000 for all five States (table 2). Trends can be noted when total withdrawal is separated by source of water for the individual States, as is shown in the relatively large increases in ground-water withdrawal of 324 percent in Nevada and 208 percent in Utah during that time. Ground-water withdrawal increased 147 percent in New Mexico; this included a large increase between 1950 and 1955. Ground-water withdrawal increased 52 percent in California and decreased 15 percent in Arizona. One factor that influenced the increases in ground-water withdrawal during the 1950s was the expanded use of large turbine pumps for irrigation of crops. 
Water-Use Trends, 1950 to 20009

Table 2. Freshwater withdrawal by water-use category and source in Arizona, California, Nevada, New Mexico, and Utah, 1950-2000

[In thousands of acre-feet]

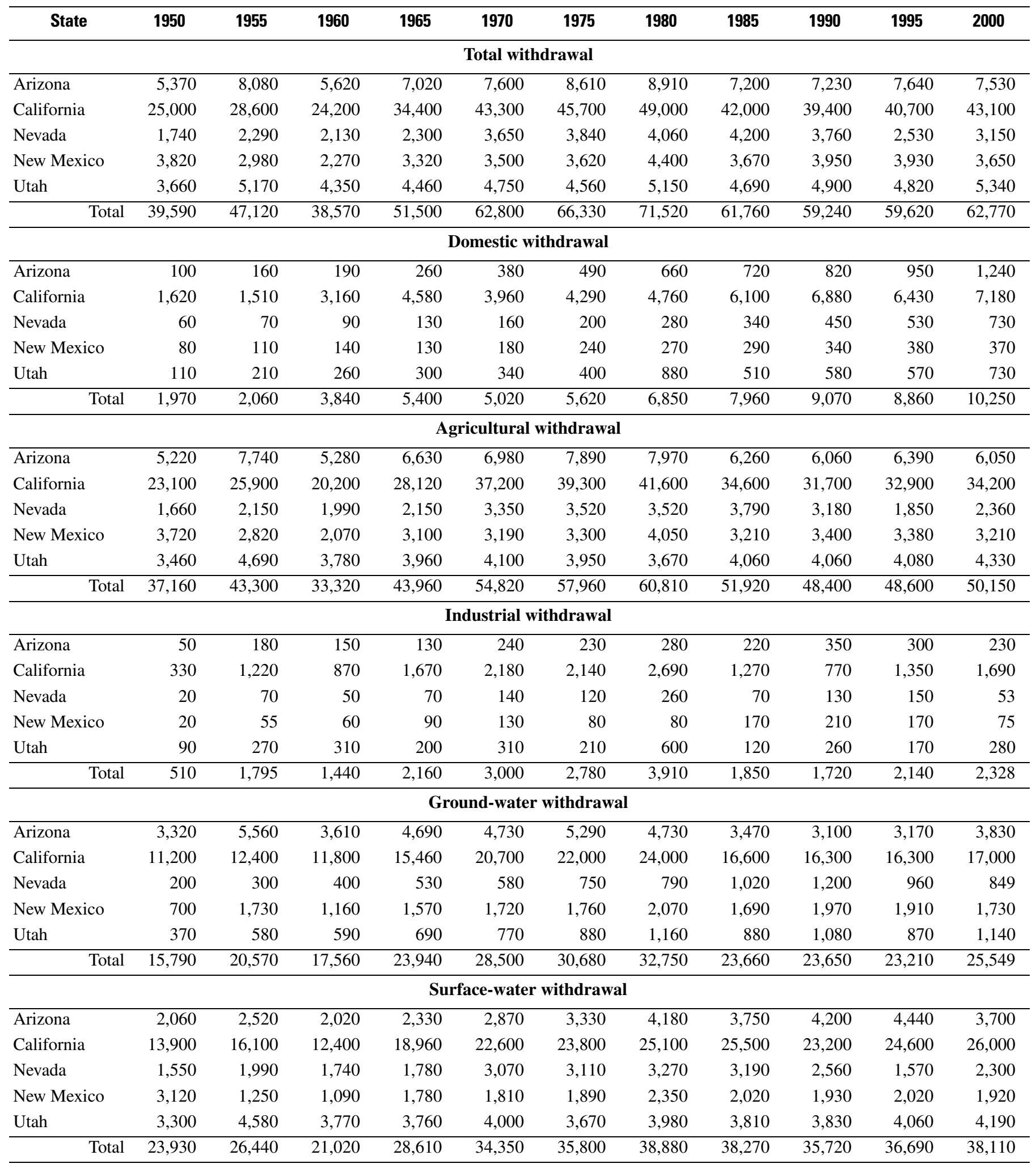




\section{Water-Use Trends in the Desert Southwest-1950-2000}

Table 3. Freshwater withdrawal by water-use category and source in the California, Great Basin, lower Colorado, and Rio Grande water-resources regions, 1965-1995

[In thousands of acre-feet]

\begin{tabular}{|c|c|c|c|c|c|c|c|c|}
\hline Region & & 1965 & 1970 & 1975 & 1980 & 1985 & 1990 & 1995 \\
\hline California & & 35,900 & 43,700 & 46,000 & 49,300 & 42,100 & 39,700 & 40,900 \\
\hline Great Basin & & 6,050 & 7,510 & 7,620 & 8,300 & 9,080 & 8,070 & 6,760 \\
\hline Lower Colorado & & 7,400 & 8,070 & 9,530 & 9,750 & 8,280 & 8,690 & 8,920 \\
\hline \multicolumn{9}{|c|}{ Domestic withdrawal } \\
\hline California & & 4,580 & 3,960 & 4,290 & 4,750 & 6,100 & 6,800 & 6,430 \\
\hline Great Basin & & 333 & 390 & 458 & 948 & 614 & 701 & 694 \\
\hline Lower Colorado & & 336 & 464 & 612 & 849 & 964 & 1,240 & 1,360 \\
\hline \multicolumn{9}{|c|}{ Agricultural withdrawal } \\
\hline California & & 29,200 & 38,200 & 39,300 & 42,700 & 34,800 & 32,200 & 33,100 \\
\hline Great Basin & & 5,410 & 6,660 & 6,780 & 6,670 & 8,340 & 7,100 & 5,820 \\
\hline Lower Colorado & & 6,860 & 7,320 & 8,460 & 8,540 & 7,070 & 6,900 & 7,230 \\
\hline Rio Grande & & 7,250 & 6,320 & 5,530 & 4,860 & 5,620 & 5,970 & 6,790 \\
\hline & Total & 48,720 & 58,500 & 60,070 & 62,770 & 55,830 & 52,170 & 52,940 \\
\hline \multicolumn{9}{|c|}{ Industrial withdrawal } \\
\hline California & & 1,720 & 2,200 & 1,770 & 2,800 & 1,270 & 821 & 1,370 \\
\hline California & & 15,700 & 20,200 & 21,300 & 23,500 & 16,600 & 16,100 & 16,400 \\
\hline Great Basin & & 1,230 & 1,230 & 1,570 & 1,790 & 1,850 & 2,210 & 1,800 \\
\hline Lower Colorado & & 4,820 & 5,040 & 5,600 & 5,040 & 3,700 & 3,450 & 3,360 \\
\hline Rio Grande & & 3,590 & 2,690 & 2,580 & 2,130 & 1,880 & 2,400 & 2,160 \\
\hline & Total & 25,340 & 29,160 & 31,050 & 32,460 & 24,030 & 24,160 & 23,720 \\
\hline \multicolumn{9}{|c|}{ Surface-water withdrawal } \\
\hline California & & 20,200 & 23,500 & 24,700 & 25,800 & 25,600 & 23,500 & 24,500 \\
\hline Great Basin & & 4,820 & 6,170 & 6,050 & 6,500 & 7,230 & 5,860 & 4,960 \\
\hline Lower Colorado & & 2,470 & 3,140 & 3,920 & 4,710 & 4,600 & 5,100 & 5,570 \\
\hline Rio Grande & & 4,480 & 4,260 & 3,360 & 3,140 & 4,390 & 4,320 & 5,310 \\
\hline & Total & 31,970 & 37,070 & 38,030 & 40,150 & 41,820 & 38,780 & 40,340 \\
\hline
\end{tabular}


In Arizona, ground water was the main source of water until the early 1980s when the CAP began delivering Colorado River water to Maricopa, Pinal, and Pima Counties. In 2000, 51 percent of the total withdrawal was from ground water (fig. $\mathbf{4 A}$ ). Between 1995 and 2000 there was a 10 percent decline in irrigated acreage in Arizona and a 17 percent decrease in surfacewater withdrawals, which accounted for the proportional change in ground-water and surface-water withdrawals.

Ground-water withdrawal data are available for basins in Arizona from 1915 to 1995, 1998, and 2000 (Anning and Duet, 1994, Tadayon and others, 1998, 1999,2000 , and 2001). An example of changing wateruse trends is shown in figure 5, which includes total ground-water withdrawals in Arizona and the Upper Santa Cruz Basin, precipitation recorded in a rain gage near Tucson, Ariz., and mean annual rainfall data for the period of record. The figure shows that ground-water withdrawal in the Upper Santa Cruz Basin, which is mostly in Pima County, increased from 1934 to 1952, and fluctuated until 1968 when another period of increasing withdrawal began because of population growth in Pima County. Periods of greater than average precipitation in 1978, 1982 through 1984, and 1990 through 1994 were coincident with decreased ground-water withdrawal.

California, which has the largest total water withdrawal in the country, has a complex waterdistribution and delivery system. Much of the available water is in the northern part of the State, but the population and water needs are greatest in the southern and central parts of the State where the climate is arid to semiarid. Between 1960 and 1980, ground-water withdrawal in California more than doubled, but then declined 31 percent between 1980 and 1985 and remained well below the 1980 level through 2000. Surface-water withdrawal followed a similar trend through 1980, with minor fluctuations through 2000 (fig. $4 B$ ). Possible reasons for the apparent decline in withdrawal include water-conservation implementation, changes in water allocation, and water-use reporting practices.

Prior to 1980, more than 80 percent of the water needs for Nevada were met by surface water. Since 1980 , the trend has been less use of surface water and more use of ground water (fig. $4 C$ ). The ground-water portion of the total water withdrawal increased from 11 percent in 1950 to 27 percent in 2000 . The changes in ground-water withdrawal may also be the result of differences in reporting of ground-water withdrawal.
From 1950 to 2000 ground-water withdrawal in New Mexico increased from 18 percent of the total water withdrawal to 47 percent. New Mexico is primarily dependent on surface water to meet its water-use needs, but because of the variability in streamflow, the State occasionally uses more ground water than surface water, as was the case in 1955, 1960, and 1990 (fig. 4D).

Utah, like New Mexico, is primarily dependent on surface water for most uses. During most years, surface water is more than 80 percent of the water withdrawal in Utah. Ground-water withdrawal was 10 percent of the total withdrawal in 1950 and 19 percent of the total withdrawal in 2000 (fig. $4 E$ ).

Ground-water withdrawal data have been collected annually in Utah since 1963 and are reported by wateruse category for 35 areas where ground-water resources have been developed. Fifteen areas are considered to have "significant" ground-water development (fig. 3).

From 1964 to 2000 ground-water withdrawals in the Salt Lake Valley (Salt Lake City area) were greater than withdrawals from any other basin in Utah. A total of 110,000 acre-ft of ground water was pumped in the valley in 1963, and 145,000 acre-ft of ground water was pumped in 2000, an increase of more than 30 percent. It was also the area with the largest withdrawal for domestic and industrial use. Ground-water withdrawal for domestic use increased from 32,500 acre-ft in 1964 to 93,800 acre-ft in 2000.

Ground-water withdrawal in Utah and in Salt Lake Valley, precipitation at Salt Lake City airport, and mean annual rainfall are shown in figure $\mathbf{6}$. Because ground water is used to supplement surface-water supplies used for agriculture, there is an increase in ground-water withdrawal during years with below average rainfall. During years with above average rainfall, there is a decrease in ground-water withdrawal. For example, figure 6 shows that from 1987 to 1990, when the precipitation in Salt Lake City was below average, ground-water withdrawal, correspondingly, increased.

Water withdrawal data by county are available in 5-year periods from 1985 to 2000. Sixty-nine of 152 counties in the 5 Southwestern States showed declines in water withdrawals that ranged from 1 to 72 percent between 1985 and 2000. Total water withdrawal increased from 1 to 709 percent in the other 81 counties, and 2 counties had no change.

The Basin and Range Physiographic Province incorporates all or parts of 58 counties in the 5 Southwestern States (fig. 2). The areas of the counties within each State in the Basin and Range Physiographic Province represent 65 percent of Arizona, 29 percent of California, 42 percent of New Mexico, 42 percent of Utah, and 100 percent of Nevada. Overall, these counties represent 53 percent of the total area of the five States. 


\section{A. Arizona}
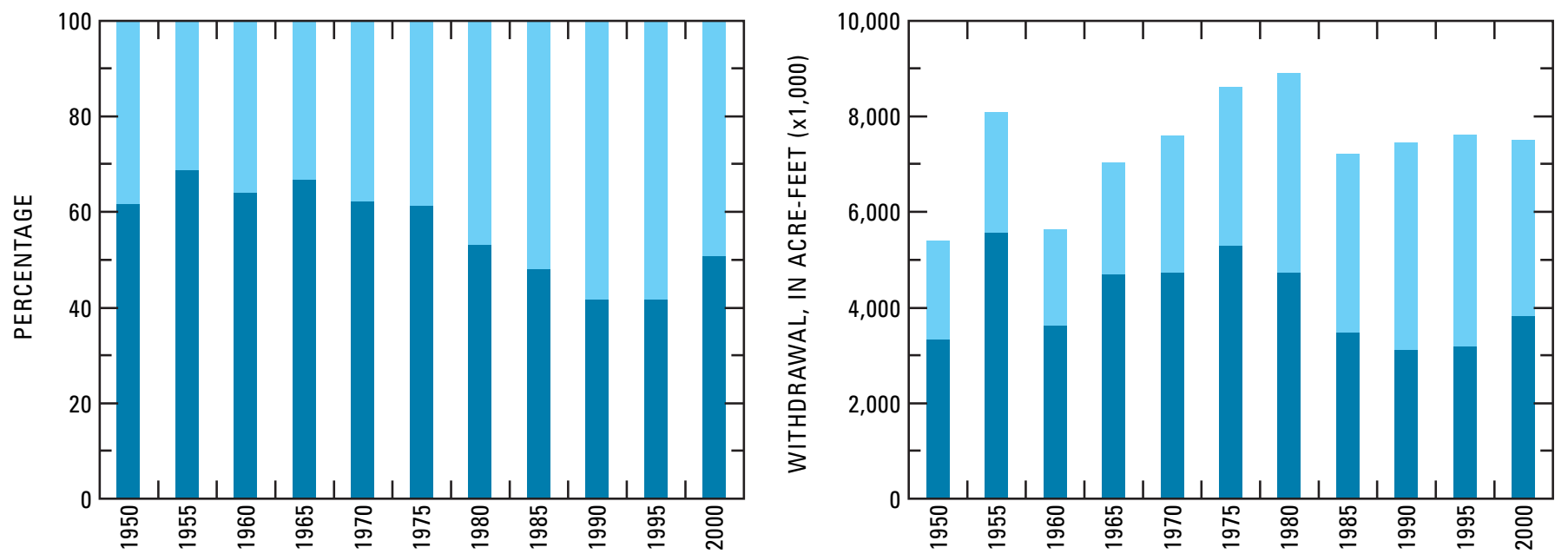

B. California
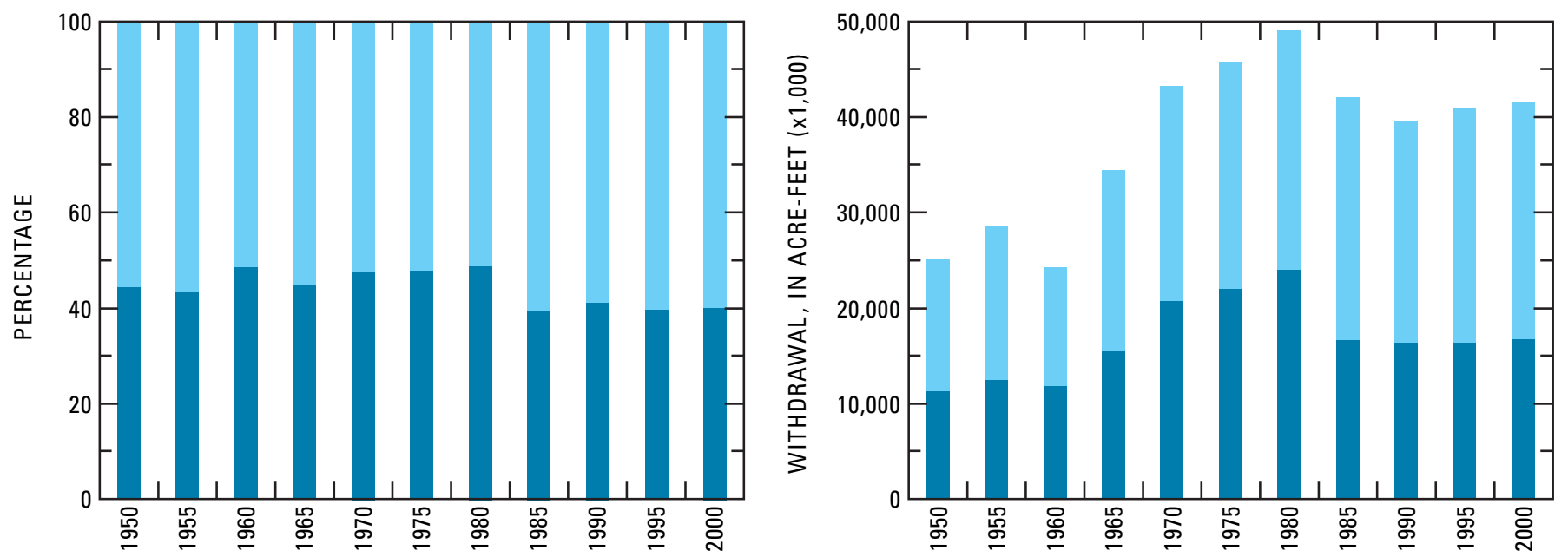

C. Nevada
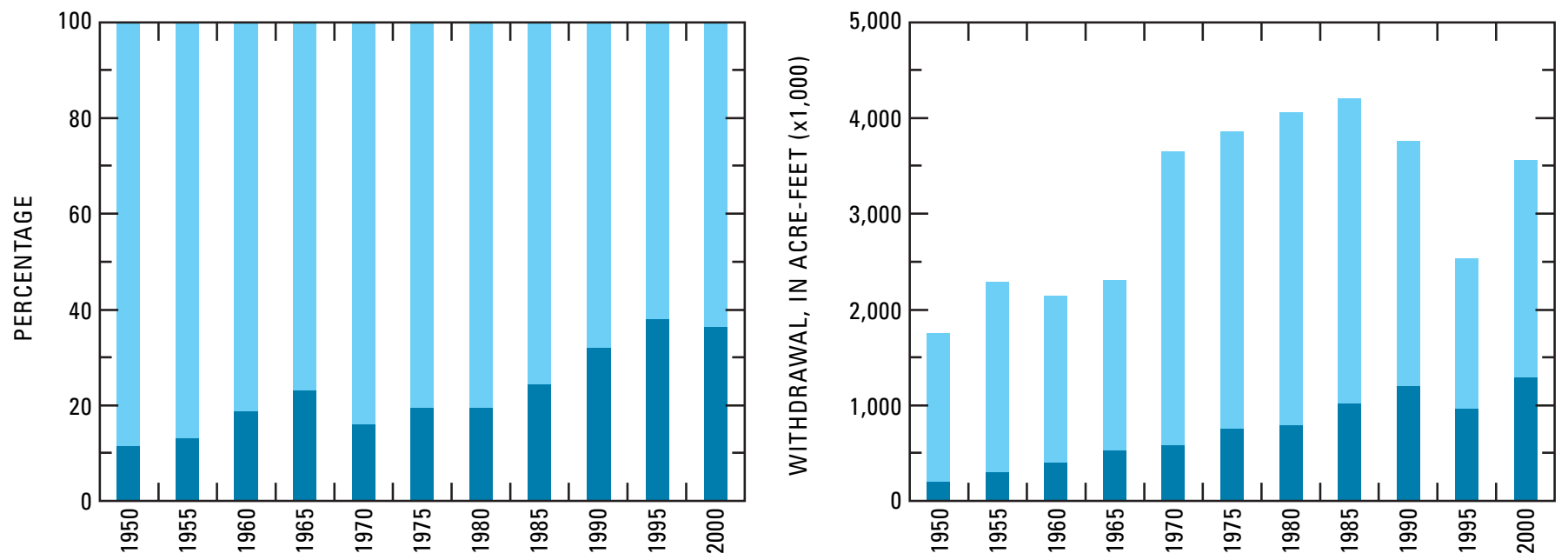

Figure 4. Ground-water and surface-water withdrawal and percentage of total withdrawal that is ground water and surface water, 1950-2000. A, Arizona; $B$, California; $C$, Nevada; $D$, New Mexico; $E$, Utah. 
D. New Mexico

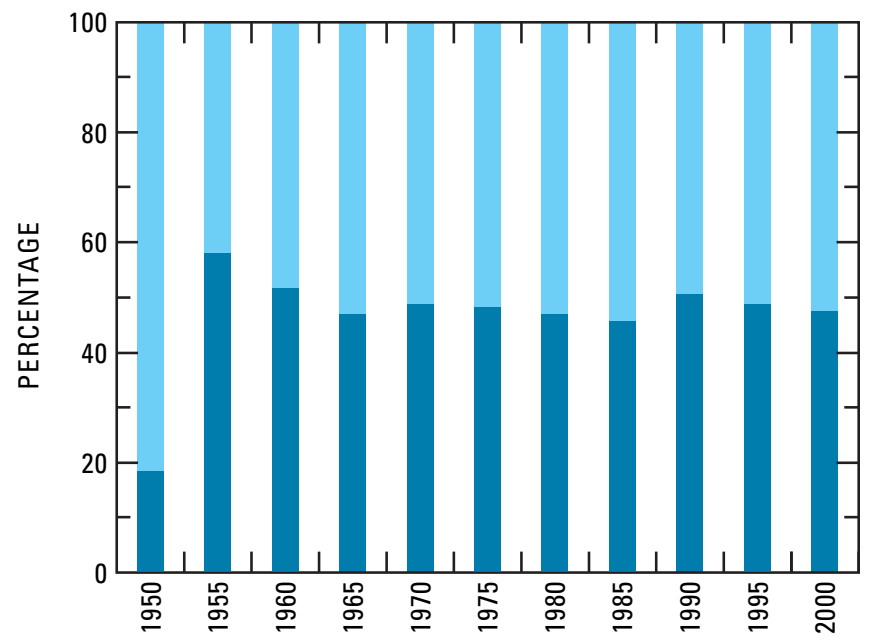

E. Utah

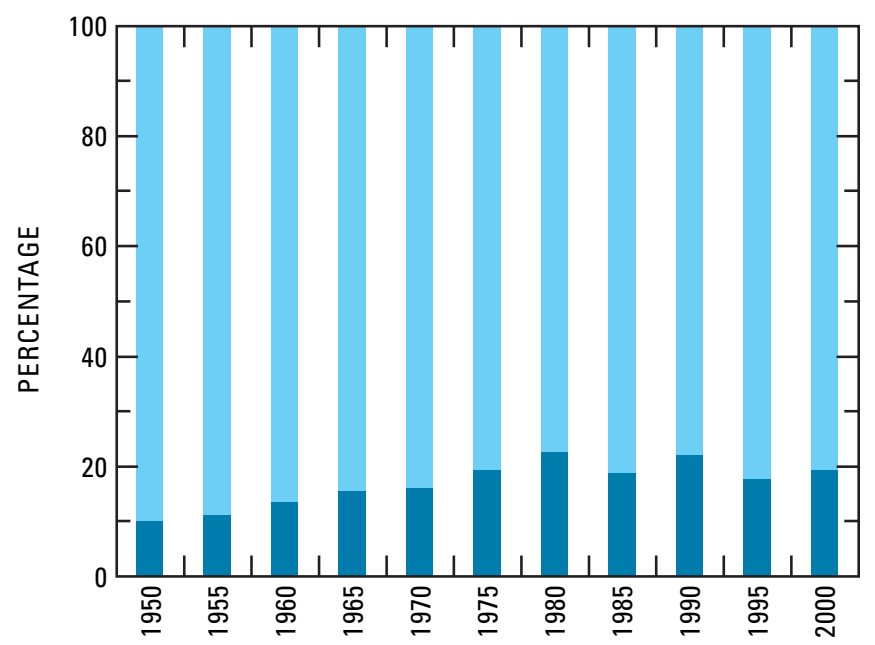

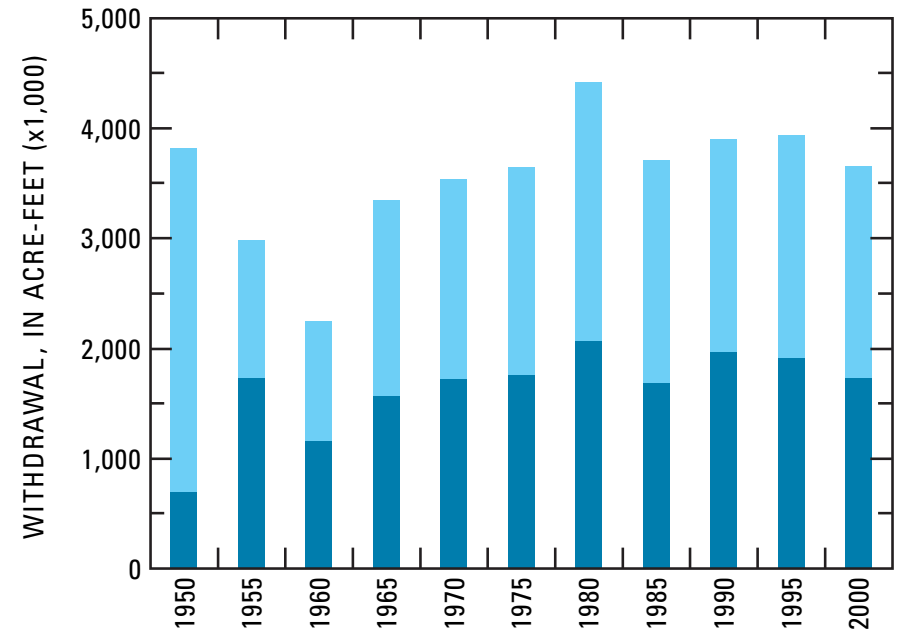

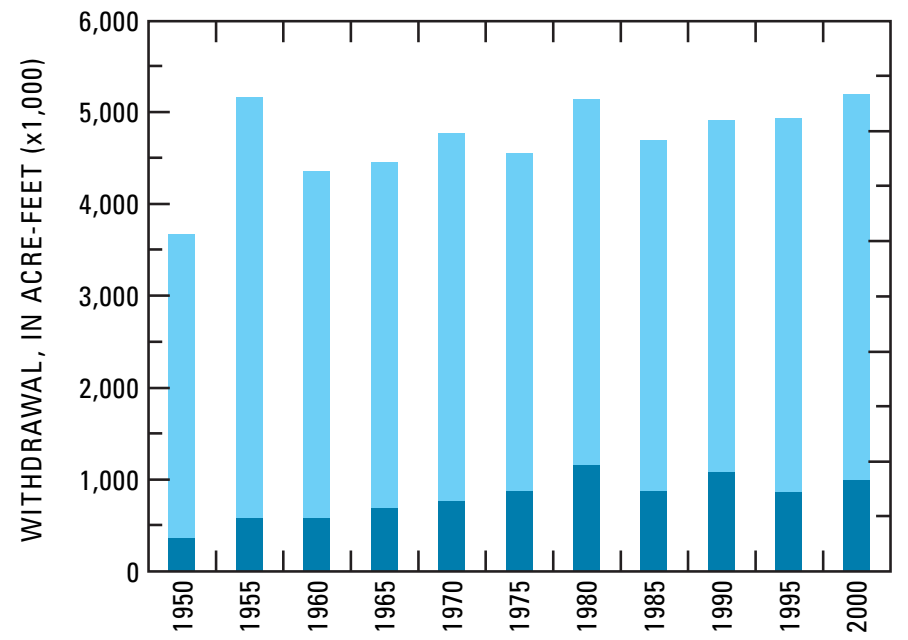

EXPLANATION

Ground water Surface water

Figure 4. Continued. 


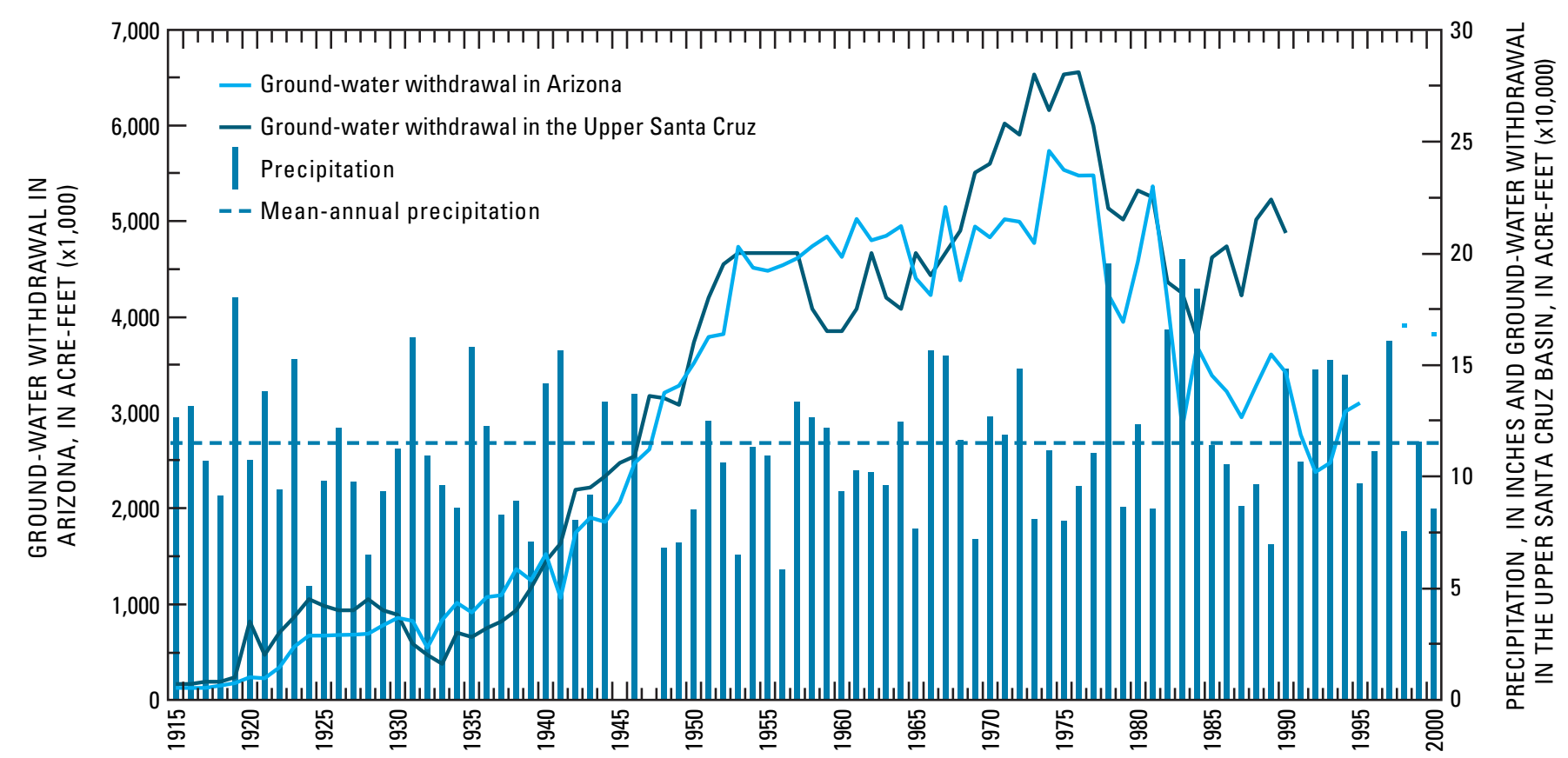

Figure 5. Ground-water withdrawal in Arizona and the Upper Santa Cruz Basin and annual and mean-annual precipitation at the National Weather Service rain gage in Tucson, Arizona.

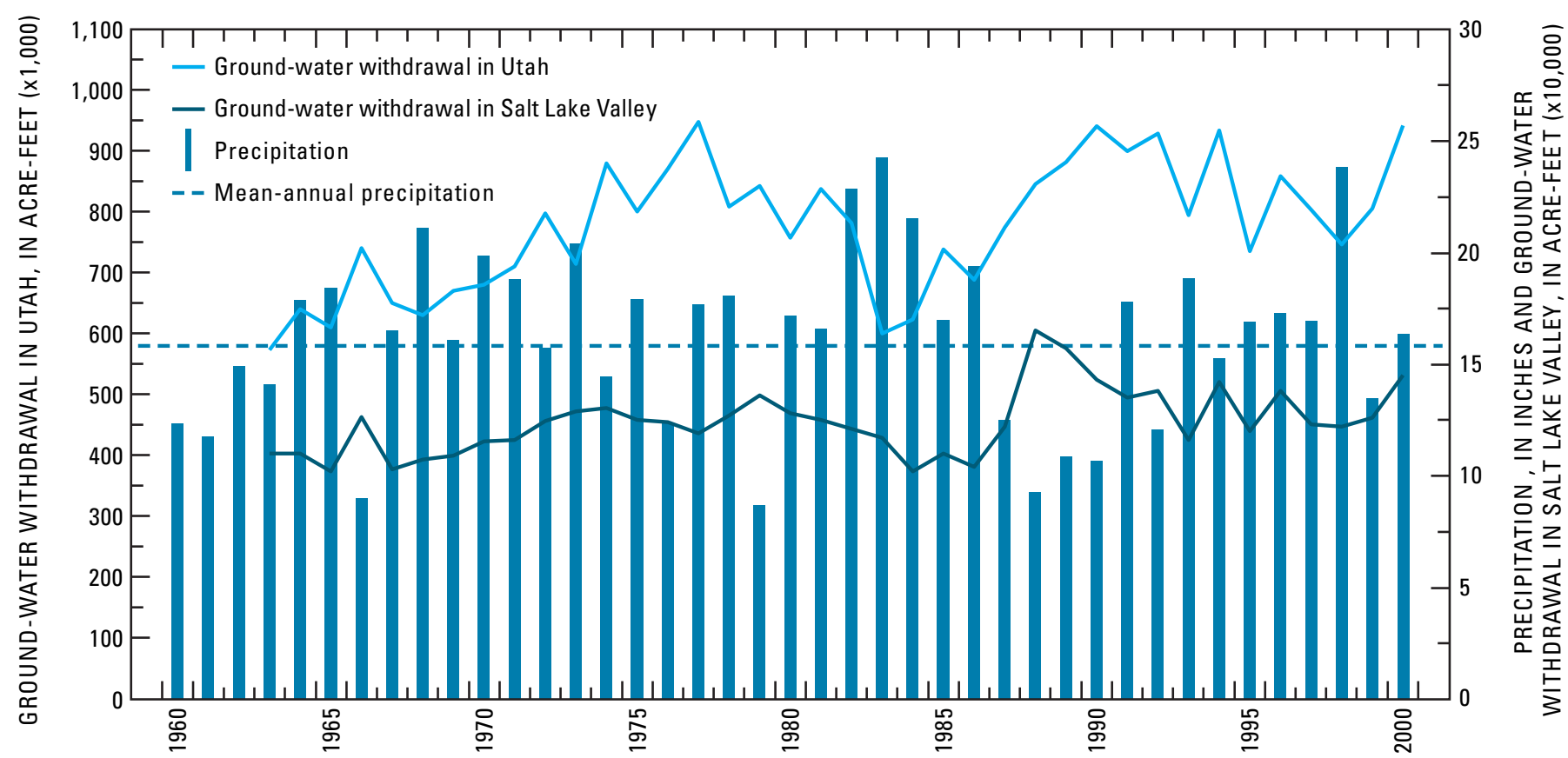

Figure 6. Ground-water withdrawal in Utah and Salt Lake Valley and annual and mean-annual precipitation at the National Weather Service rain gage in Salt Lake City, Utah. 
Total withdrawal for all the counties in the Basin and Range Physiographic Province increased 3 percent from 1985 to 2000, an overall increase of 660,000 acre-ft

(table 4). Surface-water withdrawal increased 160,000 acre-ft and ground-water withdrawal increased 500,000 acre-ft during this period. There was a decrease in total withdrawal in 26 counties and an increase in total withdrawal in 32 counties.

The county in the Basin and Range Physiographic Province with the largest increase in total withdrawal from 1985 to 2000 (450,000 acre-ft) was Imperial
County, Calif. Imperial County also had the largest increase in surface-water withdrawal $(400,000$ acre- $\mathrm{ft})$ and irrigated acreage of 114,000 acres (table 5). La Paz County, Ariz., had the largest increase in ground-water withdrawal (225,000 acre-ft). Elko County, Nev., had the largest decrease in total withdrawal (470,000 acre-ft) and the largest decrease in surface-water withdrawal (444,000 acre-ft). Pinal County, Ariz., had the largest decrease in ground-water withdrawal (116,000 acre-ft).

Table 4. Freshwater withdrawal by source in counties in the Basin and Range Physiographic Province, 1985-2000

[In thousands of acre-feet]

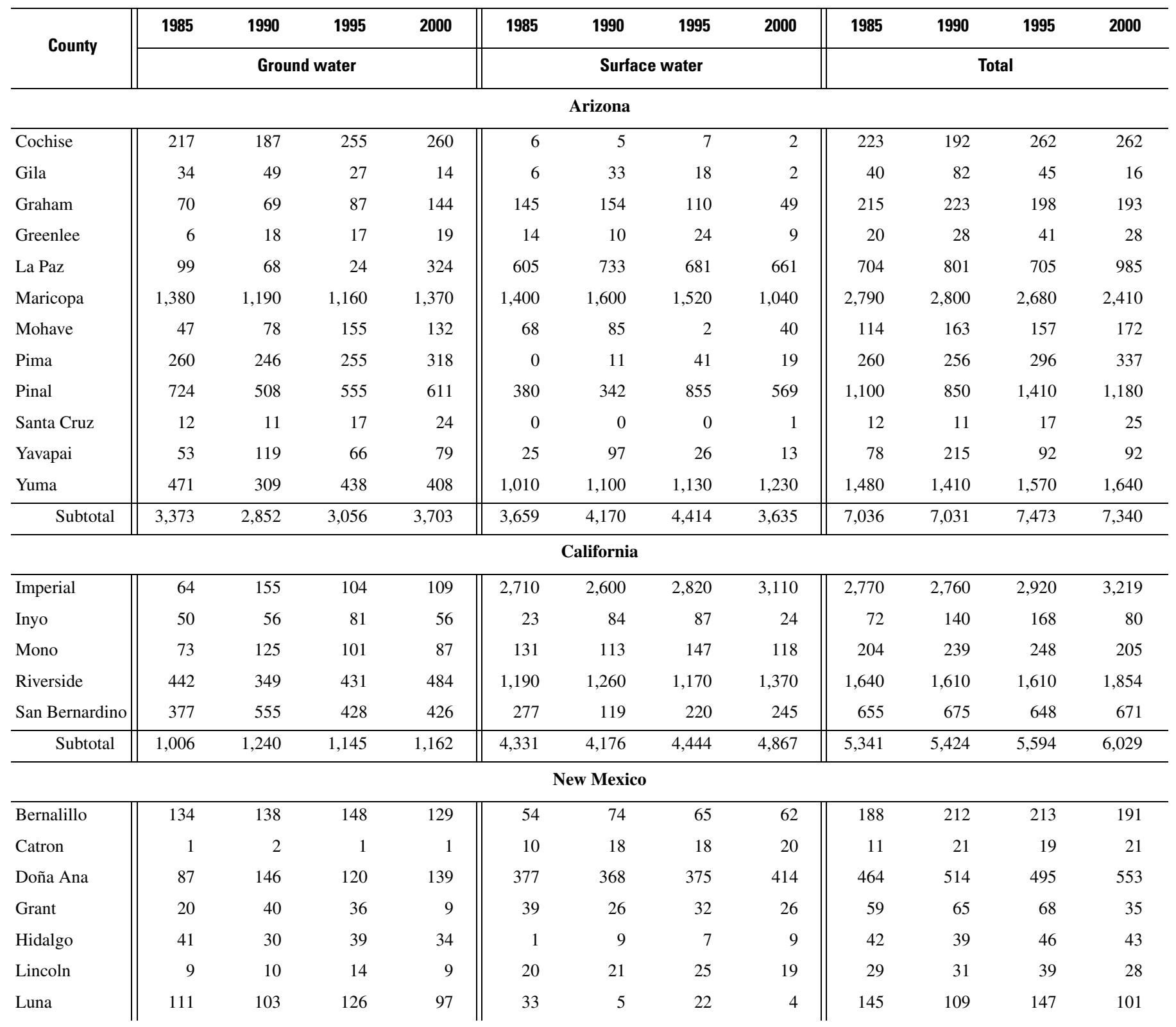


16 Water-Use Trends in the Desert Southwest-1950-2000

Table 4. Freshwater withdrawal by source in counties in the Basin and Range Physiographic Province, 1985-2000—Continued

\begin{tabular}{|c|c|c|c|c|c|c|c|c|c|c|c|c|}
\hline \multirow{2}{*}{ County } & 1985 & 1990 & 1995 & 2000 & 1985 & 1990 & 1995 & 2000 & 1985 & 1990 & 1995 & 2000 \\
\hline & \multicolumn{4}{|c|}{ Ground water } & \multicolumn{4}{|c|}{ Surface water, } & \multicolumn{4}{|c|}{ Total } \\
\hline \multicolumn{13}{|c|}{ New Mexico-Continued } \\
\hline Otero & 28 & 26 & 36 & 31 & 21 & 15 & 16 & 17 & 49 & 41 & 52 & 48 \\
\hline Sandoval & 8 & 13 & 21 & 20 & 39 & 50 & 55 & 62 & 48 & 63 & 76 & 82 \\
\hline Santa Fe & 27 & 25 & 27 & 31 & 27 & 23 & 24 & 20 & 54 & 48 & 51 & 51 \\
\hline Sierra & 10 & 14 & 19 & 13 & 28 & 26 & 29 & 24 & 38 & 40 & 47 & 37 \\
\hline Socorro & 19 & 34 & 42 & 37 & 81 & 103 & 123 & 144 & 100 & 138 & 165 & 181 \\
\hline Valencia & 7 & 16 & 19 & 16 & 127 & 132 & 183 & 162 & 134 & 148 & 202 & 178 \\
\hline Subtotal & 502 & 597 & 648 & 566 & 857 & 870 & 974 & 983 & 1,361 & 1,469 & 1,620 & 1,549 \\
\hline \multicolumn{13}{|c|}{ Nevada } \\
\hline Churchill & 17 & 30 & 21 & 15 & 342 & 259 & 136 & 162 & 359 & 289 & 157 & 177 \\
\hline Clark & 86 & 83 & 90 & 96 & 213 & 305 & 373 & 497 & 298 & 388 & 463 & 593 \\
\hline Douglas & 17 & 17 & 28 & 19 & 224 & 196 & 119 & 149 & 241 & 213 & 147 & 168 \\
\hline Elko & 73 & 79 & 62 & 47 & 986 & 838 & 340 & 542 & 1,060 & 917 & 402 & 590 \\
\hline Esmeralda & 31 & 31 & 34 & 27 & 7 & 5 & 6 & 3 & 38 & 36 & 40 & 30 \\
\hline Eureka & 119 & 140 & 94 & 79 & 68 & 47 & 17 & 44 & 187 & 187 & 111 & 123 \\
\hline Humboldt & 290 & 305 & 245 & 207 & 370 & 277 & 69 & 237 & 660 & 582 & 314 & 444 \\
\hline Lander & 60 & 75 & 74 & 60 & 105 & 73 & 33 & 49 & 165 & 149 & 107 & 110 \\
\hline Lincoln & 44 & 47 & 40 & 43 & 30 & 21 & 21 & 22 & 73 & 67 & 61 & 65 \\
\hline Lyon & 84 & 106 & 45 & 79 & 315 & 223 & 173 & 173 & 399 & 329 & 218 & 252 \\
\hline Mineral & 7 & 9 & 9 & 8 & 36 & 26 & 16 & 7 & 42 & 35 & 26 & 16 \\
\hline Nye & 47 & 55 & 67 & 43 & 42 & 8 & 14 & 16 & 89 & 63 & 81 & 59 \\
\hline Pershing & 23 & 65 & 33 & 27 & 175 & 60 & 64 & 95 & 197 & 125 & 96 & 123 \\
\hline Storey & 0 & 0 & 1 & 4 & 1 & 3 & 3 & 5 & 1 & 4 & 4 & 9 \\
\hline Washoe & 60 & 78 & 44 & 59 & 199 & 165 & 128 & 175 & 259 & 243 & 172 & 234 \\
\hline White Pine & 51 & 60 & 66 & 21 & 56 & 40 & 52 & 105 & 107 & 100 & 118 & 126 \\
\hline Carson City & 7 & 7 & 7 & 13 & 6 & 6 & 10 & 14 & 13 & 13 & 17 & 28 \\
\hline Subtotal & 1,016 & 1,187 & 960 & 847 & 3,175 & 2,552 & 1,574 & 2,295 & 4,188 & 3,740 & 2,534 & 3,147 \\
\hline \multicolumn{13}{|c|}{ Utah } \\
\hline Beaver & 48 & 51 & 45 & 59 & 70 & 79 & 100 & 81 & 119 & 129 & 145 & 140 \\
\hline Box Elder & 72 & 72 & 88 & 71 & 314 & 317 & 327 & 428 & 386 & 388 & 416 & 499 \\
\hline Cache & 45 & 47 & 40 & 49 & 217 & 353 & 289 & 281 & 262 & 400 & 328 & 330 \\
\hline Davis & 39 & 26 & 24 & 40 & 116 & 147 & 155 & 114 & 155 & 173 & 178 & 154 \\
\hline Iron & 148 & 144 & 122 & 151 & 46 & 39 & 51 & 86 & 195 & 183 & 173 & 237 \\
\hline Juab & 22 & 31 & 26 & 35 & 118 & 94 & 98 & 62 & 140 & 125 & 124 & 97 \\
\hline Millard & 84 & 124 & 86 & 105 & 199 & 182 & 232 & 352 & 283 & 306 & 319 & 457 \\
\hline Salt Lake & 94 & 155 & 97 & 108 & 324 & 349 & 336 & 265 & 418 & 504 & 433 & 373 \\
\hline Tooele & 37 & 52 & 69 & 35 & 47 & 37 & 46 & 51 & 84 & 89 & 116 & 86 \\
\hline Utah & 122 & 166 & 110 & 169 & 281 & 259 & 224 & 419 & 403 & 425 & 335 & 588 \\
\hline Weber & 37 & 56 & 34 & 41 & 208 & 219 & 249 & 201 & 244 & 275 & 283 & 242 \\
\hline Subtotal & 748 & 924 & 741 & 863 & 1,940 & 2,075 & 2,107 & 2,340 & 2,689 & 2,997 & 2,850 & 3,203 \\
\hline Total & 6,640 & 6,800 & 6,550 & 7,140 & 13,960 & 13,840 & 13,510 & 14,120 & 20,610 & 20,660 & 20,070 & 21,270 \\
\hline
\end{tabular}


Table 5. Irrigated acreage in counties in the Basin and Range Physiographic Province, 1985-2000

[In thousands of acres. Dashes indicate no data; <, value is less than the number listed]

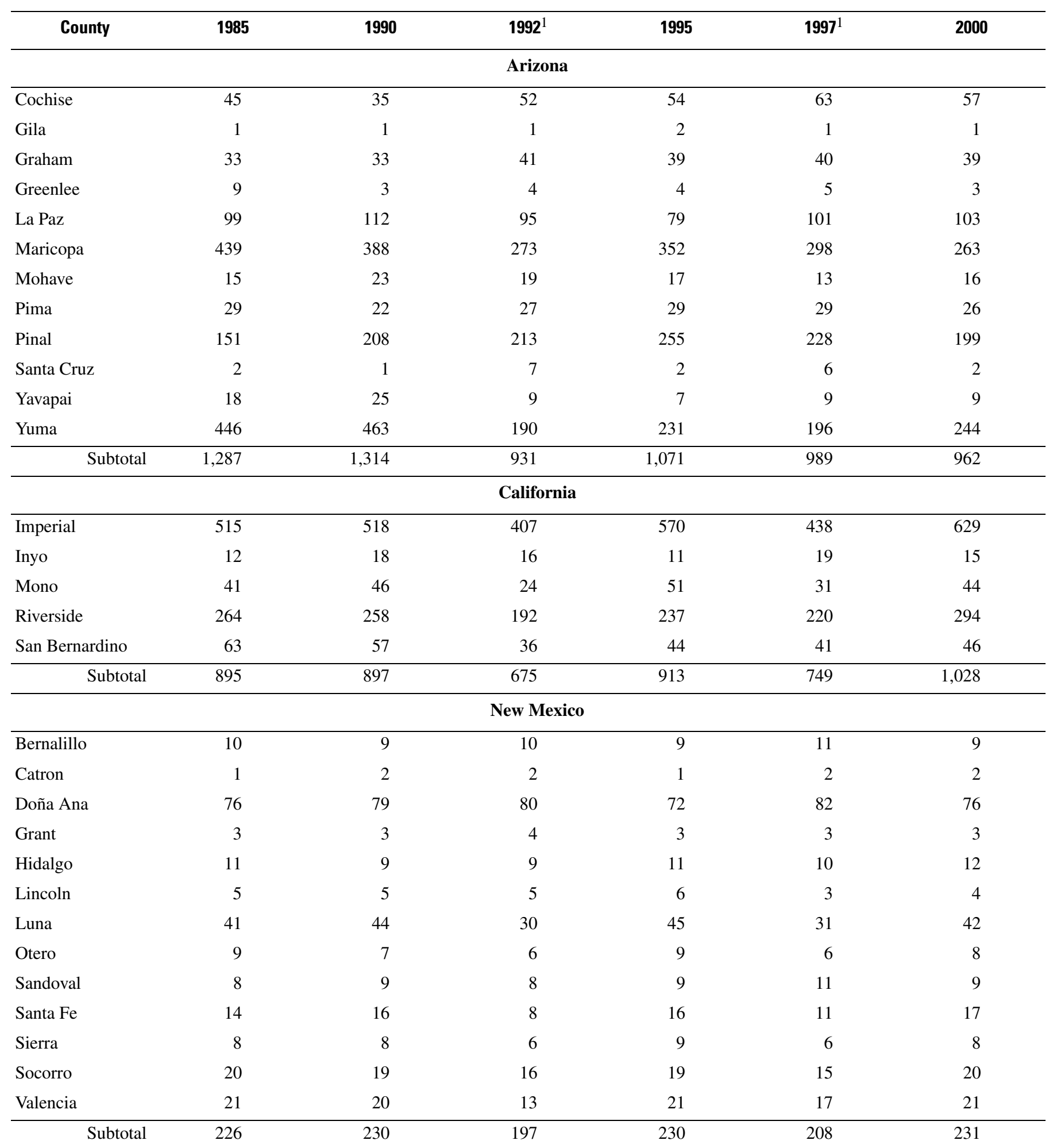

See footnote at end of table. 


\section{Water-Use Trends in the Desert Southwest-1950-2000}

Table 5. Irrigated acreage in counties in the Basin and Range Physiographic Province, 1985-2000_Continued

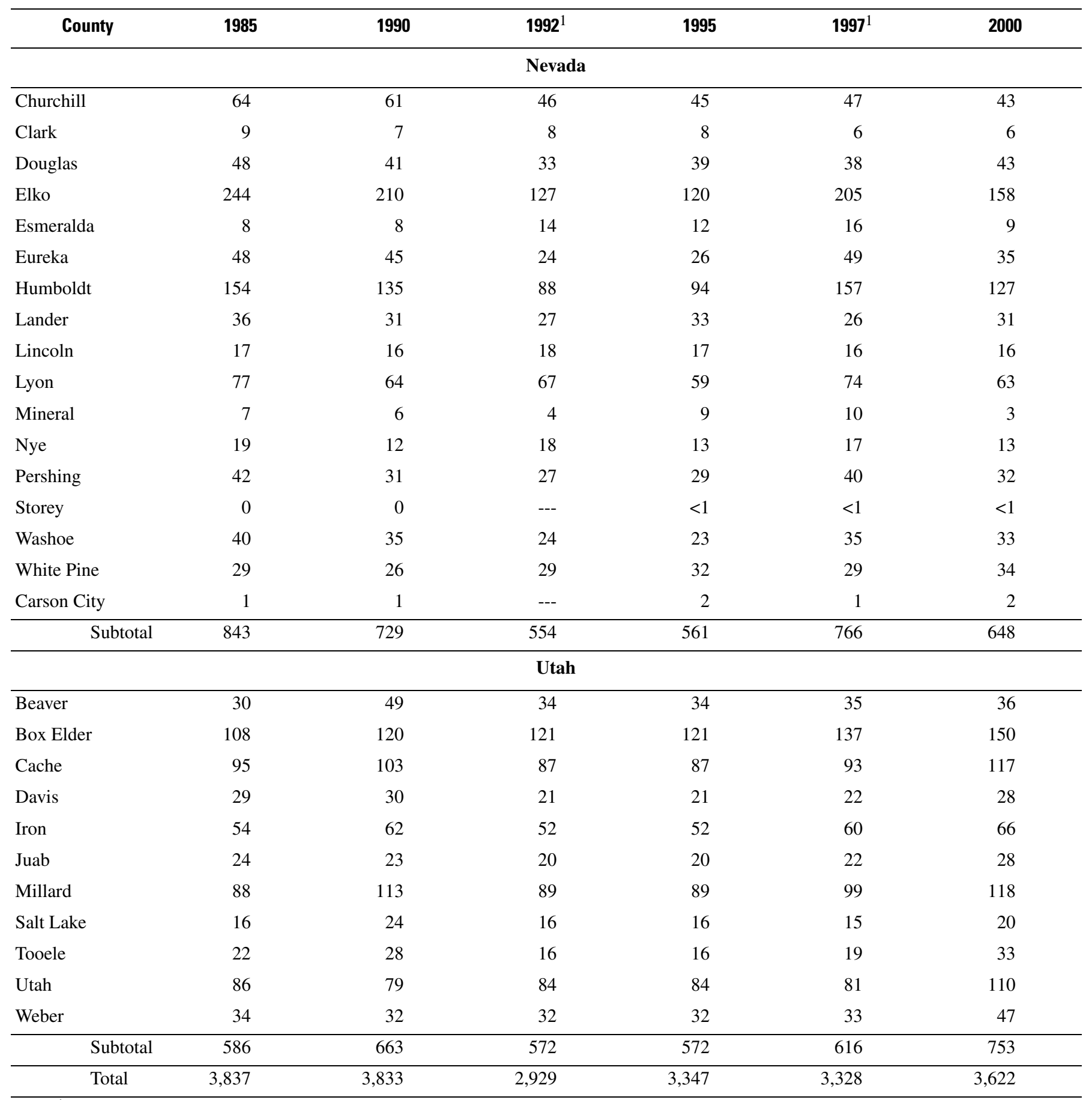

${ }^{1}$ Data from National Agricultural Statistics Service. 


\section{Domestic Water Use and Population Growth}

Even though more water is withdrawn for agriculture than for any other category in the Southwest, it is the population growth and the associated increased withdrawals for domestic uses that have the most notable increasing trends. Water withdrawals for domestic use, which, for this report, includes public supply and selfsupplied domestic water use, increased 421 percent in the five States from about 2.0 million acre-ft in 1950 to 10.2 million acre-ft in 2000 (table 2). California represented 82 percent of the total withdrawal for domestic use in 1950 and 70 percent in 2000 - the decrease due to the relative growth in the other States. The total withdrawal for domestic use in the waterresources regions and the total withdrawal for domestic use in the five States had similar changes between 1965 and 1995 of about 64 percent.

Dominated by the growth in Maricopa County, the population of Arizona increased by 4.4 million people, or 580 percent, from 1950 to 2000, and 40 percent in the last decade (table 6 and fig. 7). Between 1990 and 2000, the population of Maricopa County increased by 950,000 people, the largest increase of any county in the country during the last decade (fig. 8). With the increased population, there was a steady increase in water withdrawal for domestic use. Annual withdrawal for domestic water use increased from 100,000 acre-ft in 1950 to 1.2 million acre-ft in 2000 (fig. $9 \boldsymbol{A}$ and table 2). The increase also is reflected in the percentage of the total withdrawal that was used for domestic supply. In 1950 withdrawal for domestic use was 2 percent of the total withdrawal, and in 2000 it was 16 percent of the total withdrawal (fig. 10A). Public supply per-capita use increased in Arizona from $145 \mathrm{gal} / \mathrm{d}$ in 1960 to $219 \mathrm{gal} / \mathrm{d}$ in 2000 (table 7 and fig. 11).

Table 6. Populations of Arizona, California, Nevada, New Mexico, and Utah, 1950-2000

[In thousands. Data from U.S. Census Bureau, 2002]

\begin{tabular}{lrrrrrr}
\hline \multicolumn{1}{c}{ State } & $\mathbf{1 9 5 0}$ & $\mathbf{1 9 6 0}$ & $\mathbf{1 9 7 0}$ & $\mathbf{1 9 8 0}$ & $\mathbf{1 9 9 0}$ & \multicolumn{2}{c}{$\mathbf{2 0 0 0}$} \\
\hline Arizona & 750 & 1,302 & 1,771 & 2,718 & 3,665 & 5,131 \\
California & 10,586 & 15,717 & 19,953 & 23,668 & 29,760 & 33,872 \\
Nevada & 160 & 285 & 489 & 800 & 1,202 & 1,998 \\
New Mexico & 681 & 951 & 1,016 & 1,303 & 1,515 & 1,819 \\
Utah & 689 & 891 & 1,059 & 1,461 & 1,723 & 2,233 \\
Total & 12,866 & 19,146 & 24,288 & 29,950 & 37,865 & 45,053 \\
\hline
\end{tabular}

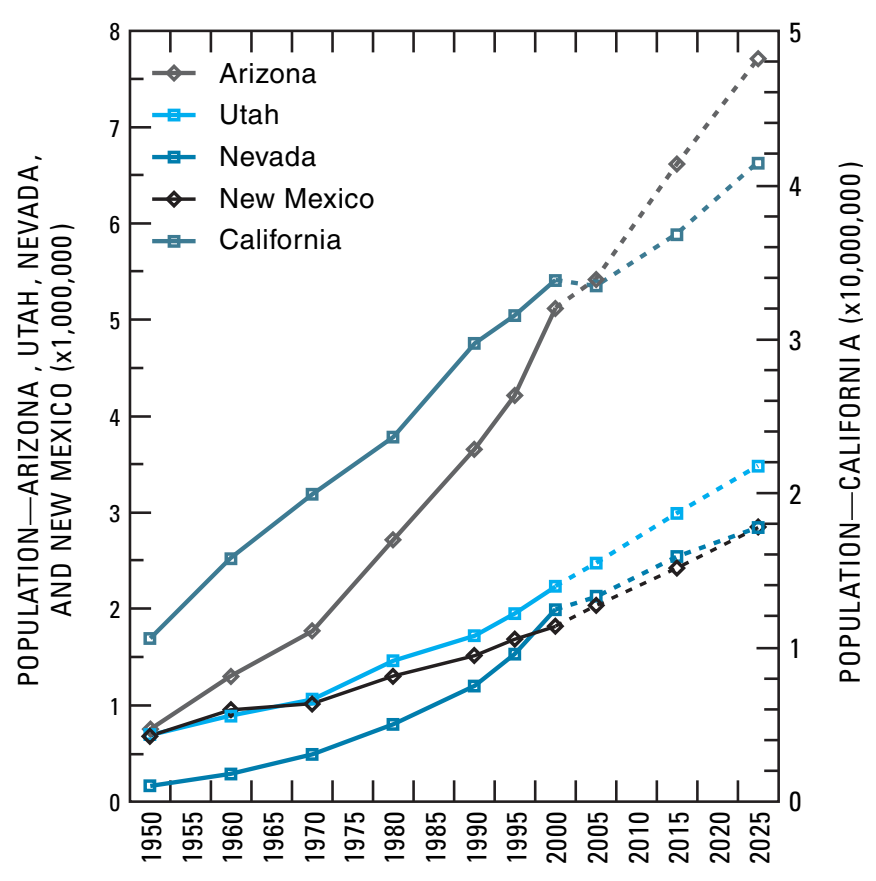

Figure 7. Population and projected population for Arizona, Utah, Nevada, New Mexico, and California, 1950-2025.

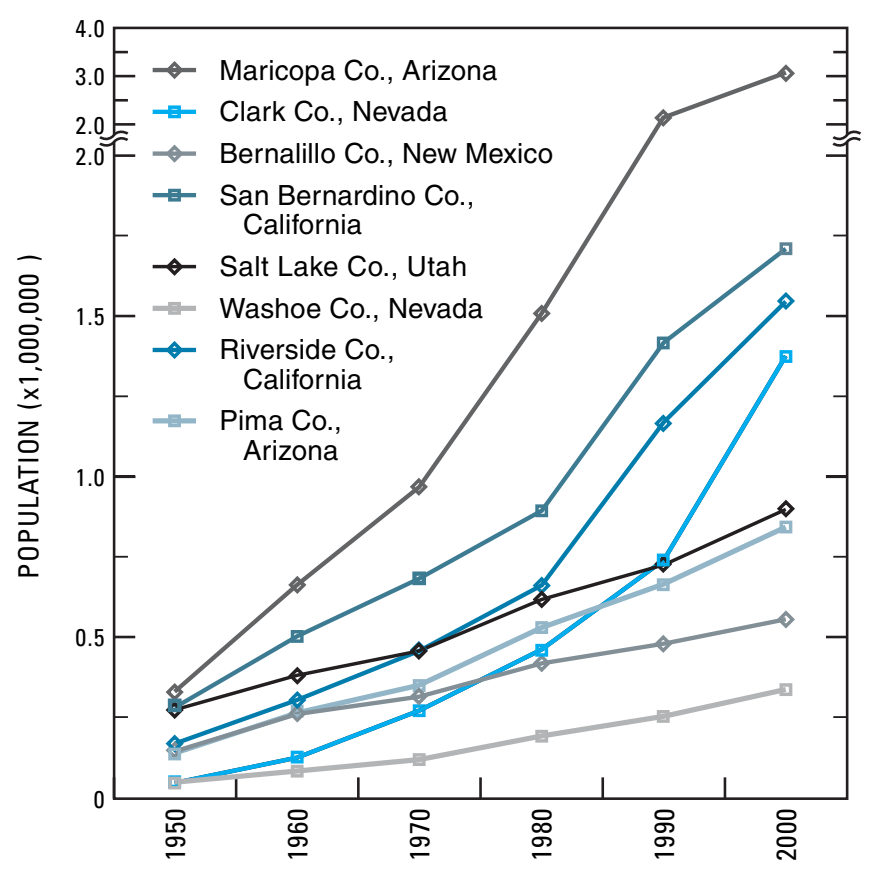

Figure 8. Population for selected counties within the Basin and Range Physiographic Province, 1950-2000. 


\section{A. Arizona}

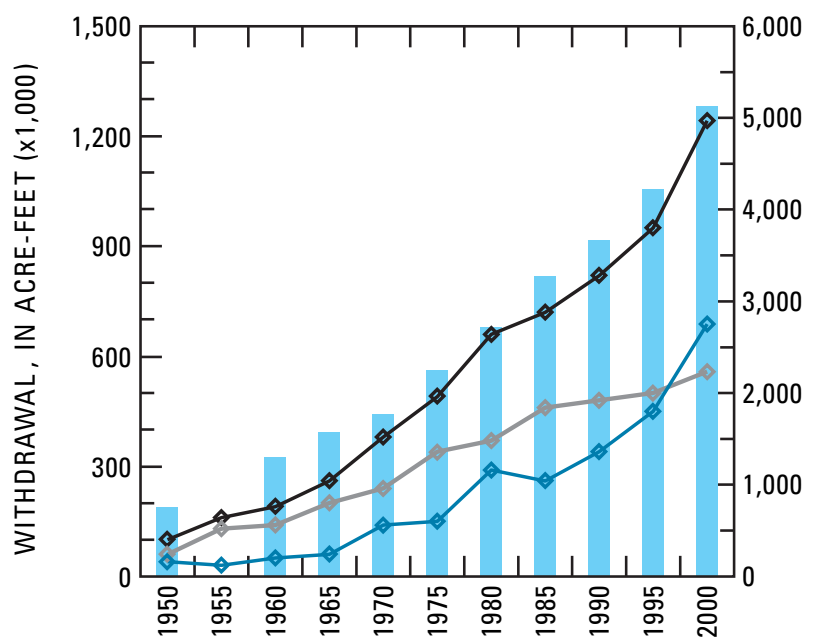

C. Nevada

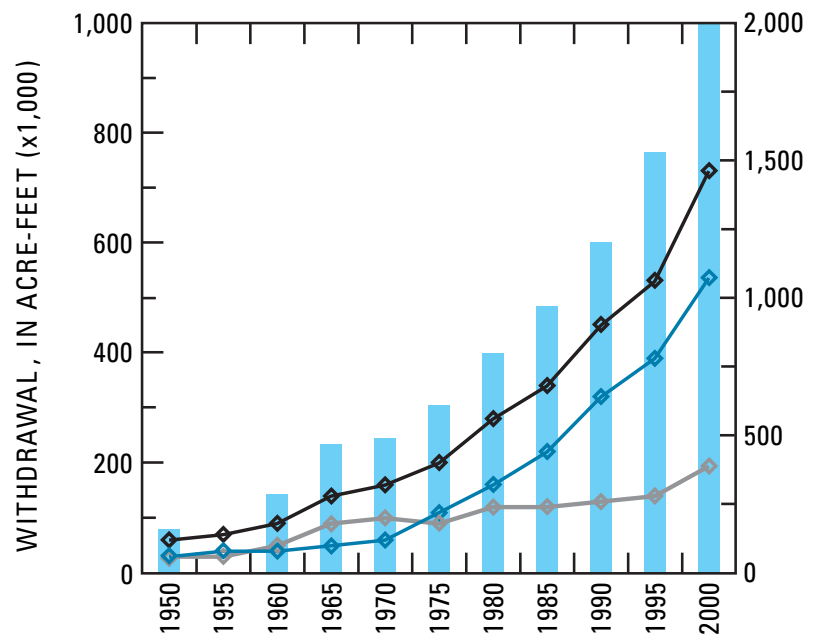

E. Utah

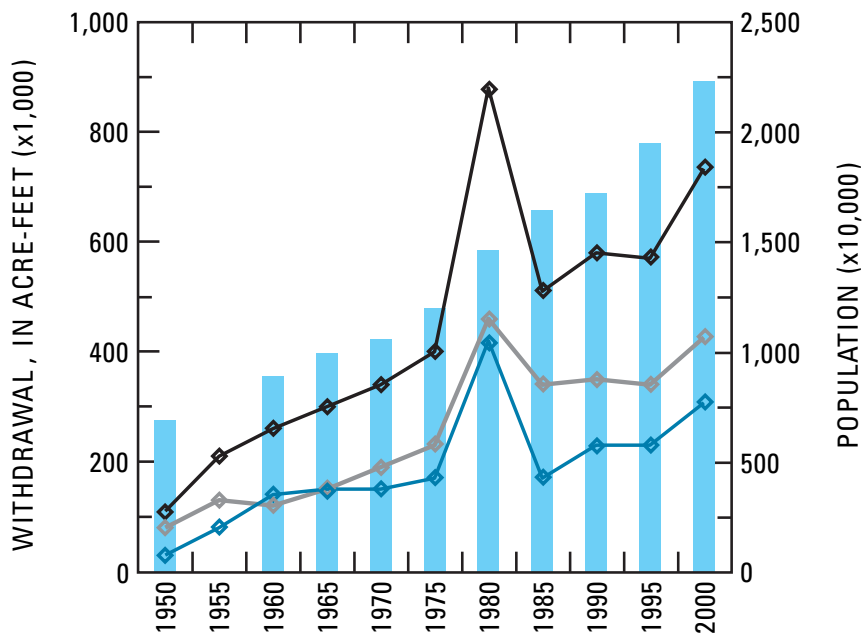

B. California

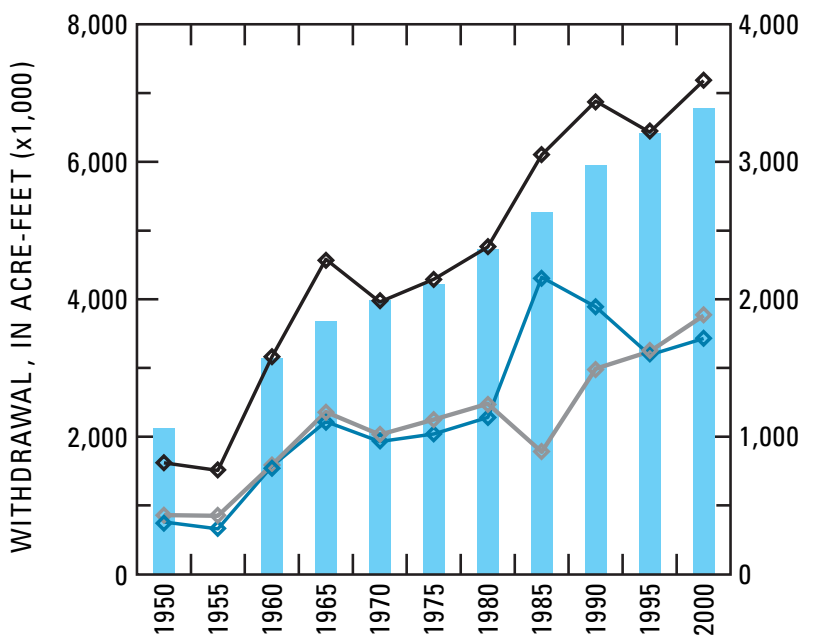

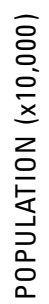

\section{New Mexico}

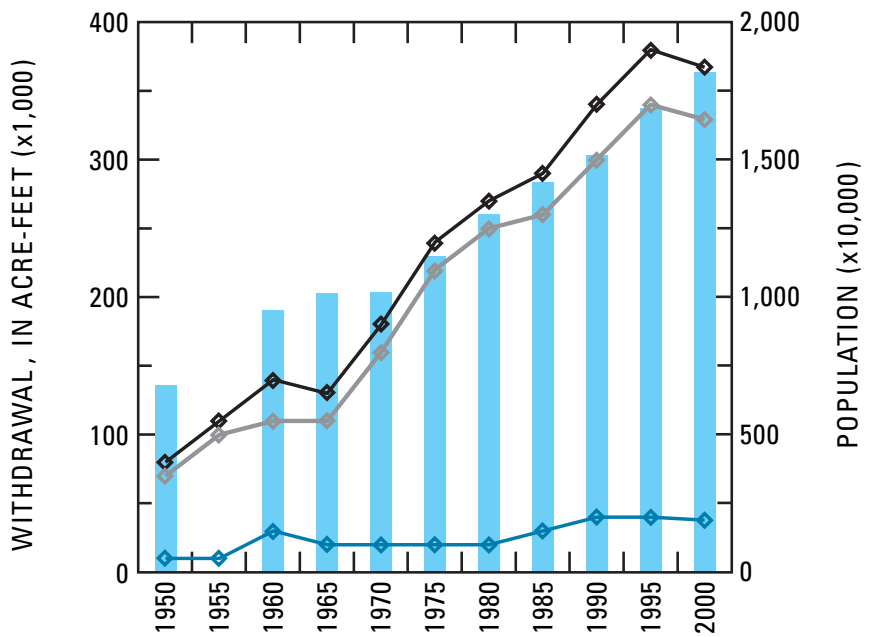

Figure 9. Population, and ground-water, surface-water, and total withdrawal for domestic water use, 1950-2000; $A$, Arizona; $B$, California; $C$, Nevada; $D$, New Mexico; E, Utah.

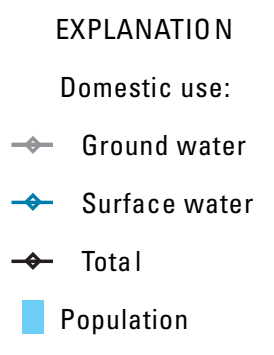

NOTE: No population data available for 1955 


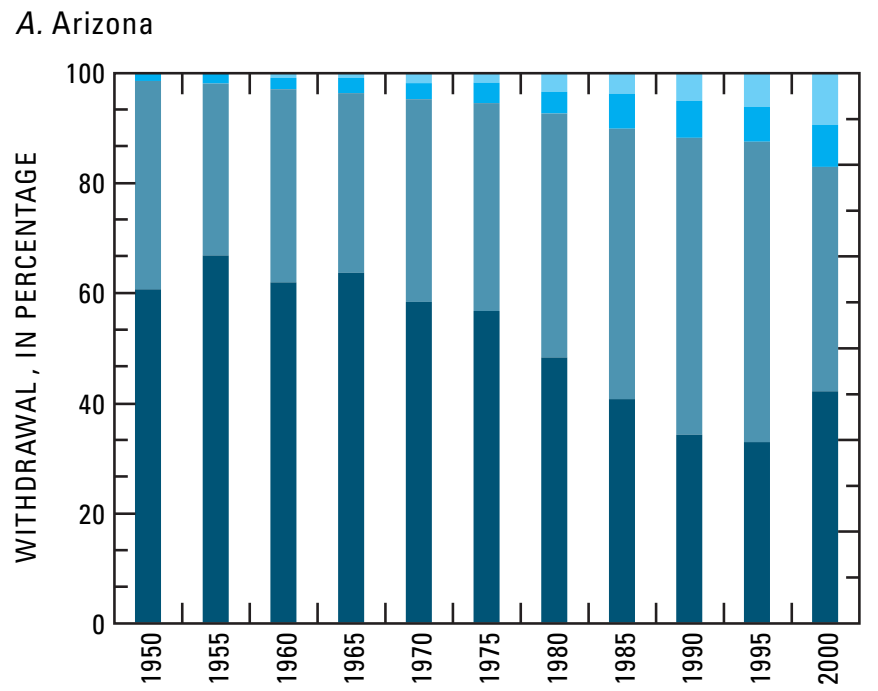

B. California

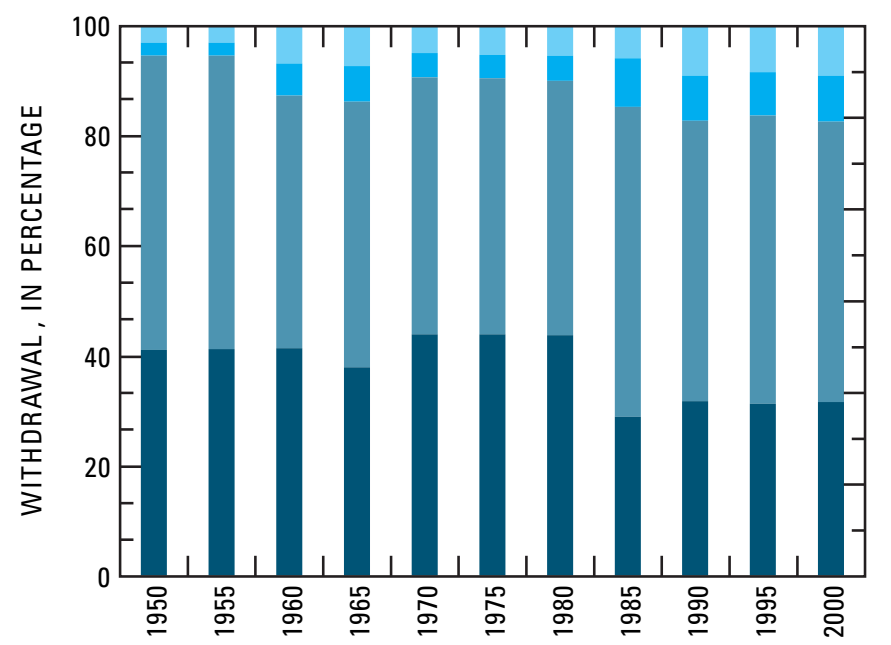

C. Nevada

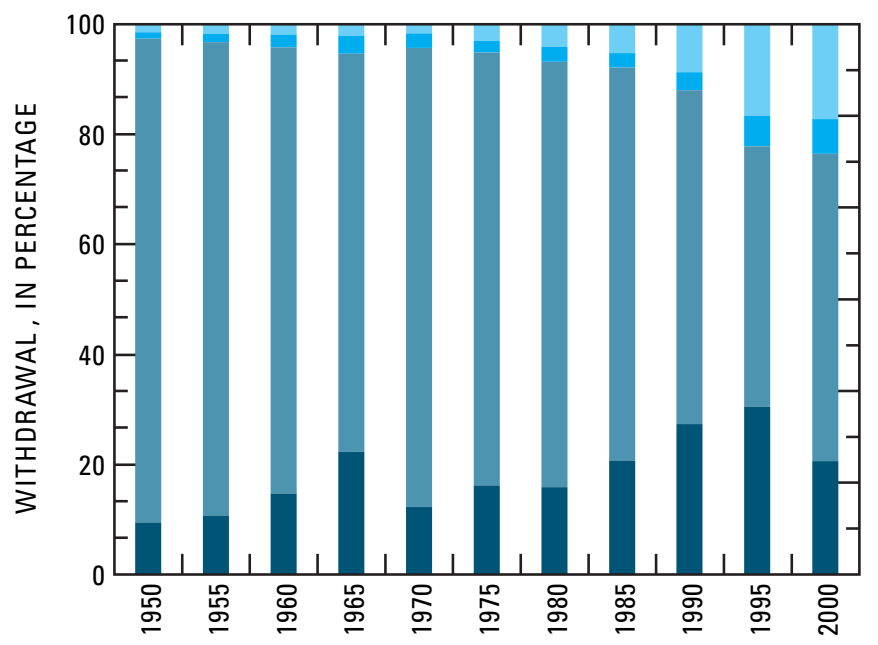

D. New Mexico

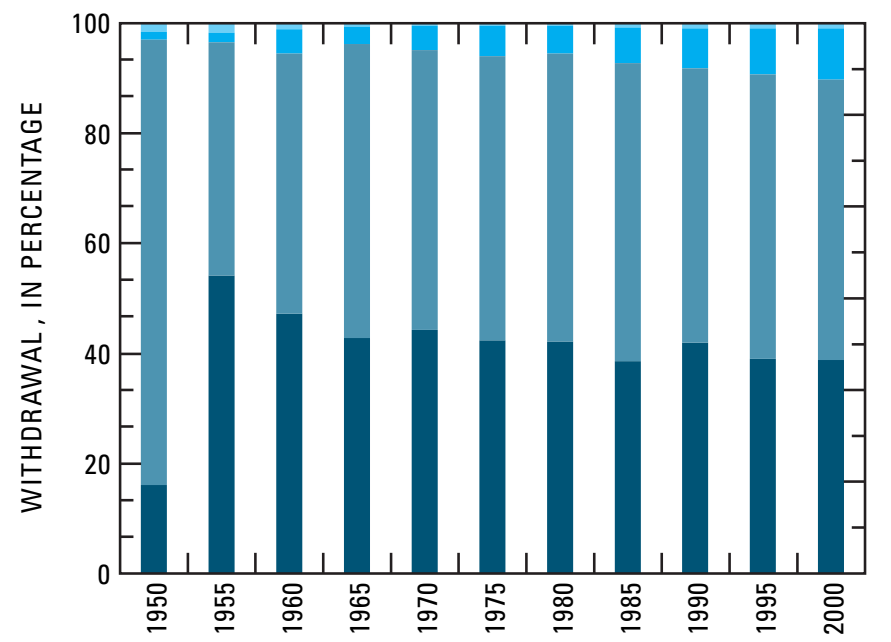

E. Utah
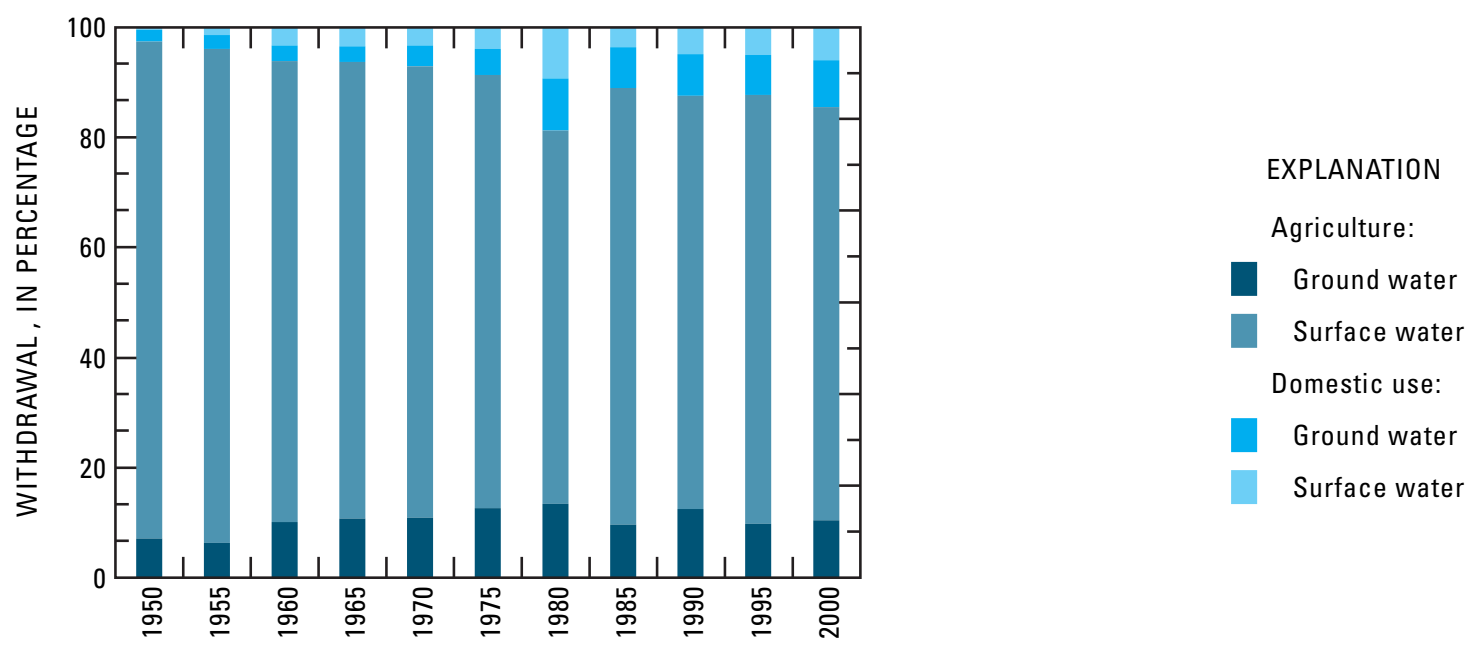

Figure 10. Percentage of ground-water and surface-water withdrawal for agricultural and domestic water uses, 1950-2000; $A$, Arizona; $B$, California; $C$, Nevada; $D$, New Mexico; E, Utah. 


\section{Water-Use Trends in the Desert Southwest-1950-2000}

Table 7. Public supply per-capita use in Arizona, California, Nevada, New Mexico, and Utah, 1960-2000

[In gallons per day. Dashes indicate no data]

\begin{tabular}{lccccccccc}
\hline \multicolumn{1}{c}{ State } & $\mathbf{1 9 6 0}$ & $\mathbf{1 9 6 5}$ & $\mathbf{1 9 7 0}$ & $\mathbf{1 9 7 5}$ & $\mathbf{1 9 8 0}$ & $\mathbf{1 9 8 5}$ & $\mathbf{1 9 9 0}$ & $\mathbf{1 9 9 5}$ & $\mathbf{2 0 0 0}$ \\
\hline Arizona & 145 & 147 & 207 & 213 & 230 & 200 & 208 & 206 & 219 \\
California & 198 & 231 & 182 & 186 & 184 & 218 & 228 & 184 & 204 \\
Nevada & 346 & 285 & 306 & 316 & 323 & 326 & 344 & 325 & 338 \\
New Mexico & 163 & 126 & 205 & 236 & 240 & 226 & 226 & 225 & 203 \\
Utah & 301 & 290 & 296 & 334 & --- & 285 & 308 & 269 & 293 \\
Weighted average & 201 & 224 & 192 & 199 & 212 & 223 & 234 & 197 & 216 \\
\hline
\end{tabular}

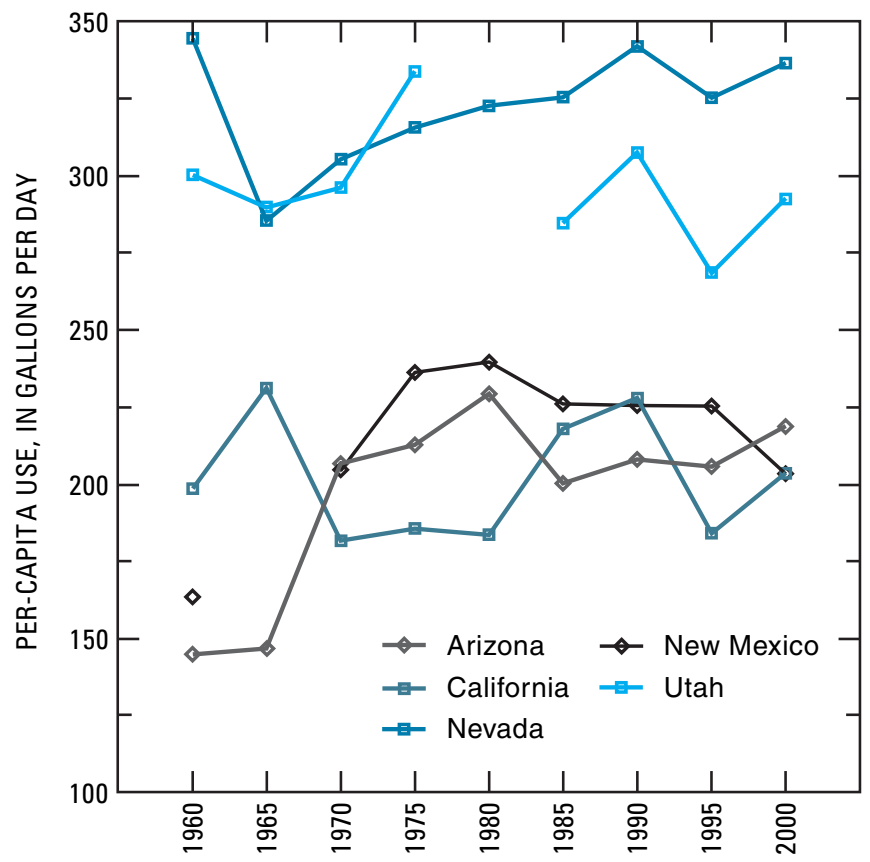

Figure 11. Per-capita use of public-supply water in Arizona, California, Nevada, New Mexico, and Utah, 1960-2000.

The population in California increased by more than 23 million, or 220 percent, between 1950 and 2000 (table 6 and fig. 7), and during that same time period, withdrawal for domestic use increased from 6.5 to 17 percent of the total withdrawal (fig. 10B). There was a decline in the amount withdrawn for domestic use from 1950 to 1955, from 1965 to 1970, and from 1990 to 1995 even though the population continued to increase, perhaps owing to water availability and waterconservation measures (fig. 9B). Public supply percapita use in California has varied between 1960 and 2000, from $182 \mathrm{gal} / \mathrm{d}$ in 1970 to $231 \mathrm{gal} / \mathrm{d}$ in 1965 (table 7 and fig. 11).
The population in the desert areas of southern California in Riverside and San Bernardino Counties are among the fastest growing in the country. Withdrawal for domestic use in the five counties in California in the Basin and Range Physiographic Province increased 28 percent from 1985 to 2000 (table 8).

The population in Nevada is increasing faster than the population of any other State in the country. From 1950 to 2000 , the population increased 1,150 percent, from 160,000 to 2.0 million (table 6 and fig. 7), and in the last decade it increased by almost 800,000, or 66 percent. Water withdrawal for domestic use in Nevada also was increased to meet the needs of the growing population. From 1950 to 2000, the domestic water-use portion of the total withdrawal increased from 3 percent to 23 percent (fig. 10C). There was some variation in the public supply per-capita use, but generally it was more than $300 \mathrm{gal} / \mathrm{d}$ (table 7 and fig. 11). Of the five States, Nevada had the largest public supply per-capita use.

Water withdrawals for domestic use in New Mexico represented 2 percent of the total withdrawal in the State in 1950 and 10 percent in 2000 (fig. 10D). Between 1950 and 2000, the population in New Mexico increased by more than 1.1 million people, or 167 percent. Public supply per-capita use in New Mexico increased from $163 \mathrm{gal} / \mathrm{d}$ in 1960 to $203 \mathrm{gal} / \mathrm{d}$ in 2000. An anomalously low public supply per-capita use value of $126 \mathrm{gal} / \mathrm{d}$ in 1965 (table 7 and fig. 11) was not considered in this report.

Water withdrawals for domestic use in Utah was 3 percent of the total withdrawals in 1950 and 14 percent of the total withdrawals in 2000 (fig. 10E). The population in Utah increased more than 220 percent, from 690,000 to 2.2 million people (table 6 and fig. 7). Public supply per-capita use ranged from $269 \mathrm{gal} / \mathrm{d}$ in 1995 to $334 \mathrm{gal} / \mathrm{d}$ in 1975 (fig. 11 and table 7). The value of $575 \mathrm{gal} / \mathrm{d}$ reported in 1980 (Solley and others, 1983, page 10) appeared anomalously large and was not considered in this report.

The percentages of withdrawal for domestic uses that was ground water varies in the five Southwestern States. Ground water was the main source of water for domestic use in New Mexico and Utah. From 1950 to 2000 more than 80 percent of the withdrawal for domestic use in New Mexico was ground water (fig. 9D). 
Table 8. Freshwater withdrawal by water-use category in counties in the Basin and Range Physiographic Province, 1985-2000 [In thousands of acre-feet]

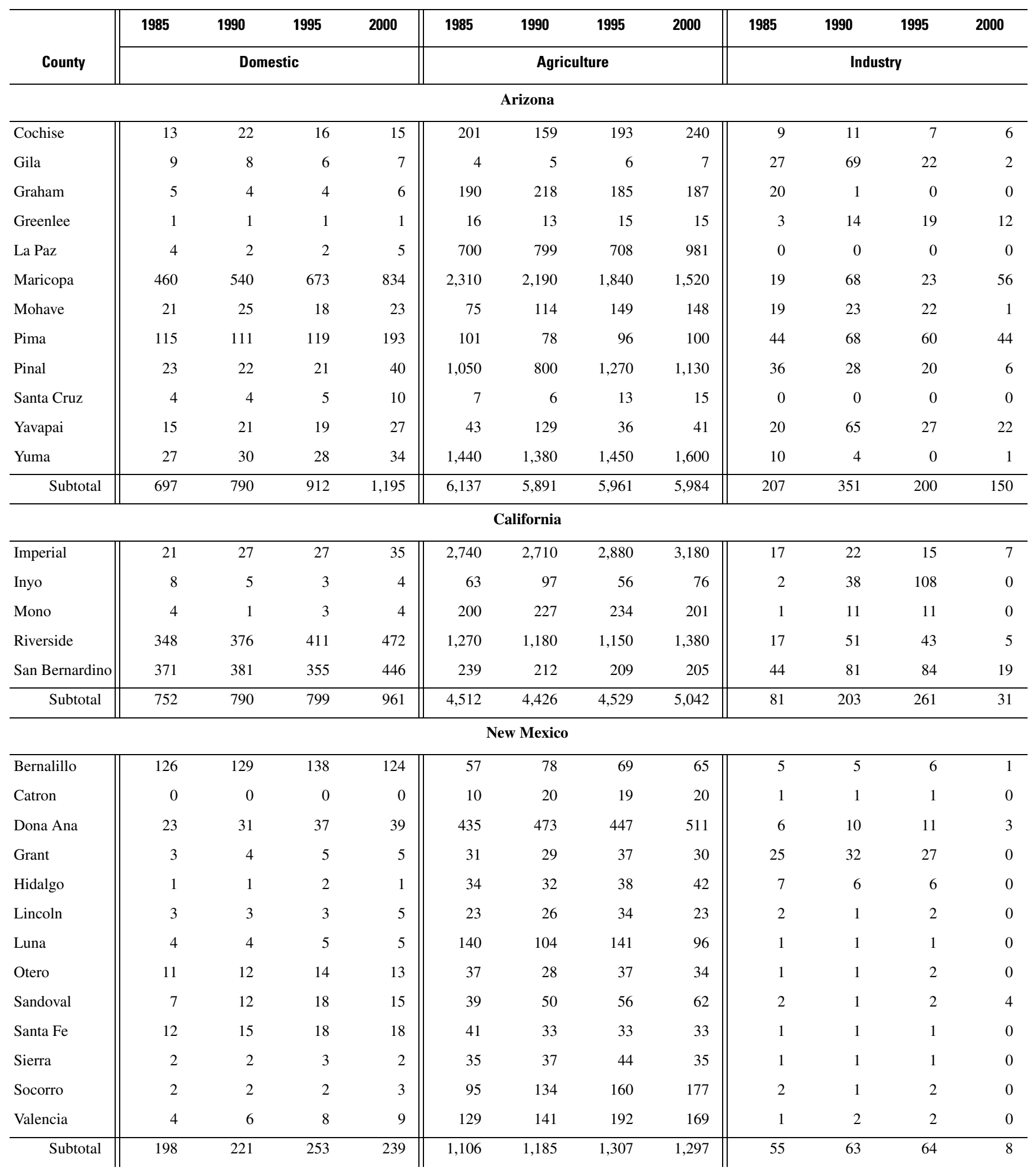




\section{Water-Use Trends in the Desert Southwest-1950-2000}

Table 8. Freshwater withdrawal by water-use category in counties in the Basin and Range Physiographic Province, 1985-2000—Continued

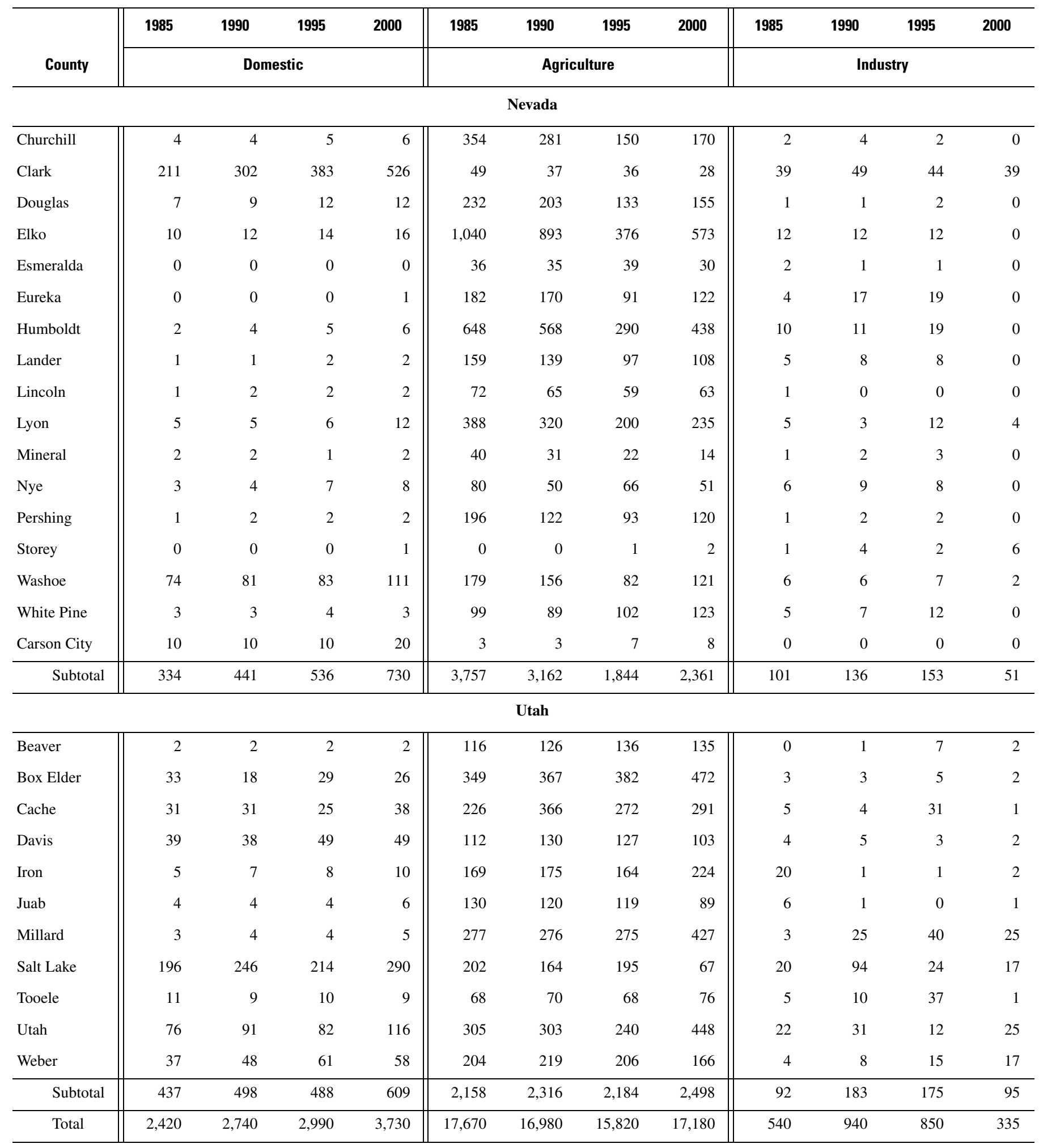


The portion of withdrawal for domestic use that came from ground water in Utah decreased from 73 percent in 1950 to 57 percent in 2000 (fig. 9E). In Arizona, ground water was the source for 81 percent of the water used for domestic purposes in 1960 and 43 percent in 2000 (fig. 9A). Generally, more surface water than ground water was used for domestic purposes in California from 1950 to 2000 (fig. 9B). The exceptions, however, were in 1985 and 1990 when more ground water was used, and in 1990 and 1995 when equal portions of ground water and surface water were used. Since 1975 surface-water withdrawals have increased more than ground-water withdrawals in order to meet domestic-supply demands in Nevada (fig. 9C). Lake Mead, along the Colorado River, is a major source of water for domestic use in the southern part of Nevada.

Public supply per-capita use presented in this report was computed on the basis of total public-supply withdrawals and the population served by the publicwater suppliers. Public-supply withdrawals include the amount of water delivered by private and public water suppliers for domestic use, and include deliveries to commercial, industrial, and thermoelectric power users.

Water-withdrawal data reported by county from 1985 to 2000 indicate that total withdrawals for domestic use for the counties in the Basin and Range Physiographic Province increased 54 percent (table 8). Surface-water withdrawal accounted for almost 80 percent of the increase. Withdrawals for domestic purposes were 12 percent of the total withdrawal in the counties in the Basin and Range Physiographic Province in 1985 and 18 percent of the total withdrawal in 2000. Of the counties within the Basin and Range Physiographic Province, Maricopa County, Ariz., which had a 22-percent decrease in ground-water withdrawal and a 183-percent increase in surface-water withdrawal, had the largest increase in withdrawals for domestic purposes from 1985 to 2000. Clark County, Nev., had the next largest increase in withdrawals for domestic purposes. This change in withdrawal also corresponds to the order in the change in population. Withdrawals for domestic use in Clark County increased 149 percent from 1985 to 2000. This increase was composed of a 190-percent increase in surface-water withdrawal and a 44-percent increase in ground-water withdrawal. The percentage of withdrawal in Clark County for domestic use increased from 71 percent in 1985 to 89 percent in 2000. During that same period, water imported from the Colorado River increased from 155,000 to 438,000 acre$\mathrm{ft}$ (Coache, 2000).

Among the five States, the largest difference between public supply per-capita use in counties in the Basin and Range Physiographic Province and public supply per-capita use in the entire State is in California (tables 7 and 9). The statewide public supply per-capita use in California is smaller by at least 30 percent for each reported year from 1985 to 2000 . The differences in percapita use is perhaps due to the arid climate in the counties in the Basin and Range Physiographic Province. There was a decline in public supply per-capita use in four of the five counties within the Basin and Range Physiographic Province in southern California. In that area the amount of water withdrawn for public-supply use increased 23 percent, while the population served increased 48 percent.

Table 9. Public supply per-capita use in counties in the Basin and Range Physiographic Province, 1985-2000

[In gallons per day]

\begin{tabular}{lllll}
\hline \multicolumn{1}{c}{ State } & $\mathbf{1 9 8 5}$ & $\mathbf{1 9 9 0}$ & $\mathbf{1 9 9 5}$ & $\mathbf{2 0 0 0}$ \\
\hline Arizona & 205 & 210 & 210 & 223 \\
California & 338 & 331 & 242 & 282 \\
Nevada & 326 & 344 & 325 & 338 \\
New Mexico & 233 & 227 & 224 & 197 \\
Utah & 277 & 300 & 263 & 284 \\
Weighted average & 268 & 272 & 244 & 261 \\
\hline
\end{tabular}

The combined population of Arizona, Nevada, New Mexico, and Utah is growing faster than the population of California. In 1950, the population of California was 10.6 million, and the combined population of the four other States was 2.3 million. By 2000, the population of California had grown to 33.9 million, an increase of 220 percent, and the combined population of the four other States in the Basin and Range Physiographic Province had grown to 11.2 million, an increase of 390 percent.

The population in the counties in the Basin and Range Physiographic Province is growing faster than the population in counties not in the Basin and Range Physiographic Province (table 10). In 1950, 18 percent of the population lived in the counties in the Basin and Range Physiographic Province compared to 30 percent in 2000.

Table 10. Percentage of State populations represented by counties in the Basin and Range Physiographic Province, 1950-2000

\begin{tabular}{lrrrrrrr}
\hline \multicolumn{1}{c}{ States } & $\mathbf{1 9 5 0}$ & $\mathbf{1 9 6 0}$ & $\mathbf{1 9 7 0}$ & $\mathbf{1 9 8 0}$ & $\mathbf{1 9 9 0}$ & $\mathbf{1 9 9 5}$ & $\mathbf{2 0 0 0}$ \\
\hline Arizona & 89 & 92 & 93 & 93 & 94 & 94 & 94 \\
California & 5 & 6 & 6 & 7 & 9 & 10 & 10 \\
Nevada & 100 & 100 & 100 & 100 & 100 & 100 & 100 \\
New Mexico & 49 & 50 & 55 & 58 & 60 & 65 & 66 \\
Utah & 83 & 87 & 89 & 88 & 88 & 87 & 87 \\
All States & 18 & 19 & 20 & 24 & 26 & 27 & 30 \\
\hline
\end{tabular}


From 1965 to 1995 , estimated withdrawal for domestic use in the four water-resources regions increased 64 percent and the total population in the four water-resources regions increased more than 80 percent (tables 3 and 11).

Table 11. Population in the California, Great Basin, lower Colorado, and Rio Grande water-resources regions, 1965-1995

[In thousands. Data from U.S. Geological Survey]

\begin{tabular}{lrrrrrrr}
\hline \multicolumn{1}{c}{ Region } & $\mathbf{1 9 6 5}$ & $\mathbf{1 9 7 0}$ & $\mathbf{1 9 7 5}$ & $\mathbf{1 9 8 0}$ & $\mathbf{1 9 8 5}$ & $\mathbf{1 9 9 0}$ & $\mathbf{1 9 9 5}$ \\
\hline Lower Colorado & 1,848 & 2,223 & 2,640 & 3,241 & 3,926 & 4,747 & 5,318 \\
Great Basin & 1,163 & 1,213 & 1,434 & 1,782 & 1,980 & 2,182 & 2,405 \\
California & 18,456 & 20,009 & 21,117 & 23,671 & 26,358 & 29,442 & 32,060 \\
Rio Grande & 1,877 & 1,617 & 1,991 & 1,775 & 2,094 & 2,229 & 2,566 \\
Total & 23,344 & 25,062 & 27,182 & 30,469 & 34,358 & 38,600 & 42,349 \\
\hline
\end{tabular}

\section{Agricultural water use and irrigated acreage}

The amount of water withdrawn for agricultural use from 1965 to 2000 in the five States increased 14 percent, while irrigated acreage increased 11 percent. Withdrawal for agriculture in California represented 64 percent of the withdrawal for agriculture in all five States in 1965 and 68 percent of the withdrawal for agriculture in 2000 . This increased withdrawal reflects increased irrigated acreage in California and decreases in acreage in other States.
The areal extent and temporal changes in irrigated acreage are important in evaluating water use. Irrigatedacreage data are generally compiled on the basis of State and county boundaries by State and Federal agencies. Several factors can affect changes in irrigated acreage from year to year that do not necessarily indicate trends in the amount of irrigated acreage. For example, with extreme climate conditions, such as drought, farmers may use more water for their crops or may use less water if they remove acreage from production. Reduction in crop market value may also prompt farmers to reduce the amount of acreage in production. Government programs, such as crop subsidies, can also effect short-term changes in irrigated acreage. In some areas, however, irrigated acreage has declined as farmland has been converted to residential use, shifting water-use type from agriculture to domestic use.

Irrigated-acreage data for 5-year intervals are available by State from the USGS for years 1965 to 2000 (table 12). The National Agricultural Statistics Service (NASS) of the U.S. Department of Agriculture published data for 4-to 5-year intervals for 1964 to 1997 (U.S. Department of Agriculture, 2002). Between the two sets of data, the irrigated acreage differs, perhaps owing to differences in reporting and compilation years; however, the trends are similar. Estimated acreage from the NASS was generally less than that reported by the USGS. Both data sets indicate an increase in irrigated acreage in the five States between the mid-1960s and 1980, a decline from 1980 through the mid-1990s, and an increase in the last reported data.

Table 12. Irrigated acreage in Arizona, California, Nevada, New Mexico, and Utah, 1964-2000

[In thousands of acres]

\begin{tabular}{|c|c|c|c|c|c|c|c|c|}
\hline State & $1965^{*}$ & $1970 *$ & $1975^{*}$ & $1980 *$ & $1985^{*}$ & $1990^{*}$ & $1995 *$ & $2000 *$ \\
\hline California & 8,500 & 8,700 & 9,000 & 9,700 & 9,580 & 9,480 & 9,480 & 10,100 \\
\hline New Mexico & 1,000 & 1,100 & 1,100 & 1,400 & 940 & 980 & 960 & 1,000 \\
\hline Utah & 1,200 & 1,300 & 1,700 & 1,200 & 1,100 & 1,290 & 1,140 & 1,410 \\
\hline State & $1964^{* *}$ & $1969 * *$ & $1974^{* *}$ & $1978 * *$ & $1982^{* *}$ & $1987^{* *}$ & $1992^{* *}$ & $1997^{* *}$ \\
\hline Arizona & 1,120 & 1,180 & 1,150 & 1,200 & 1,100 & 910 & 960 & 1,010 \\
\hline California & 7,600 & 7,240 & 7,750 & 8,510 & 8,460 & 7,600 & 7,570 & 8,710 \\
\hline Nevada & 825 & 753 & 778 & 881 & 830 & 779 & 556 & 765 \\
\hline
\end{tabular}

*Data from U.S. Geological Survey.

**Data from National Agricultural Statistics Service. 
A. Arizona

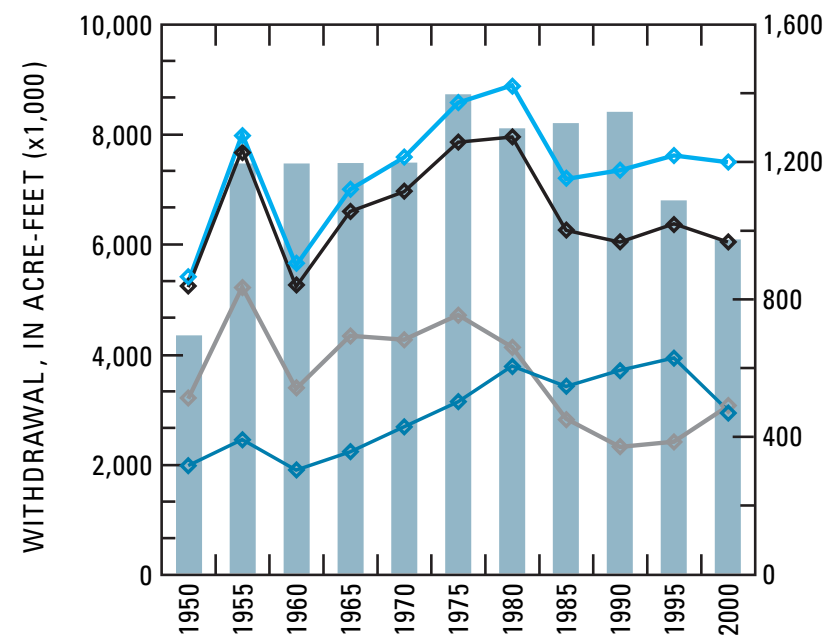

C. Nevada

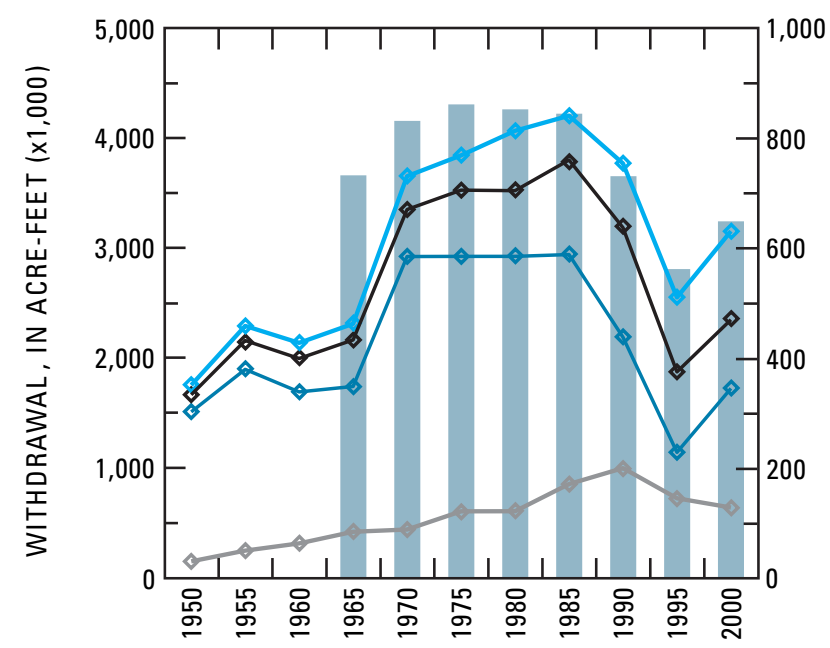

E. Utah

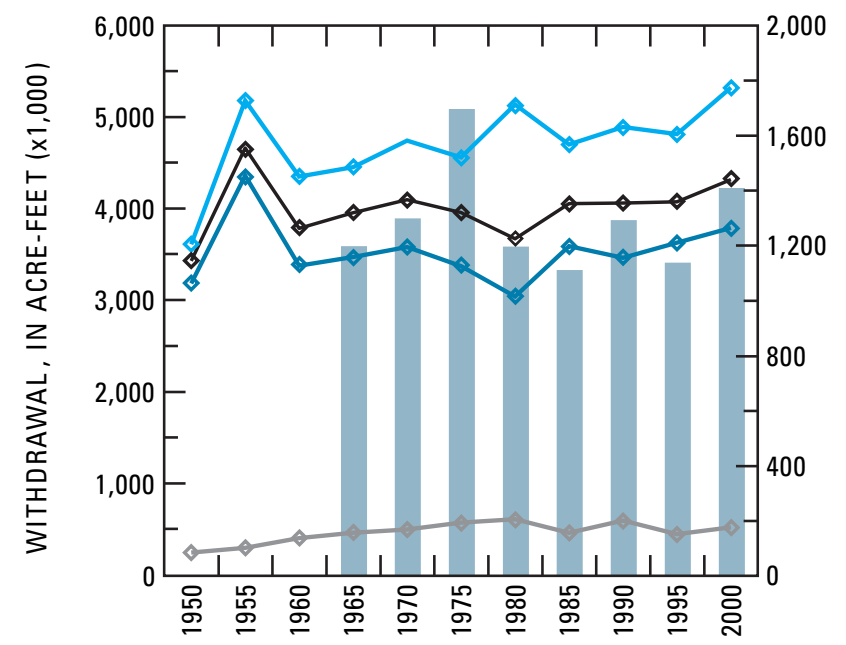

B. California

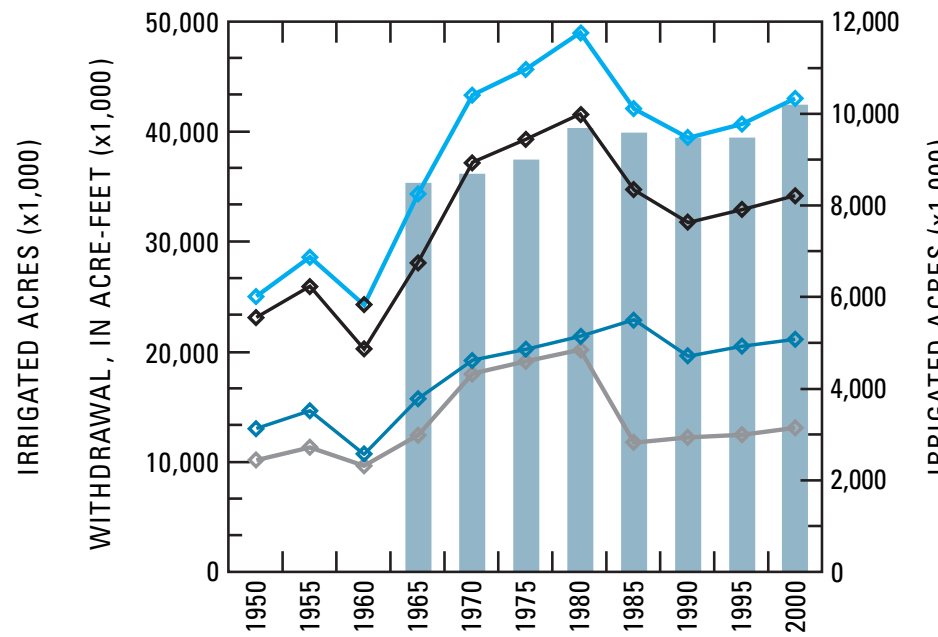

D. New Mexico

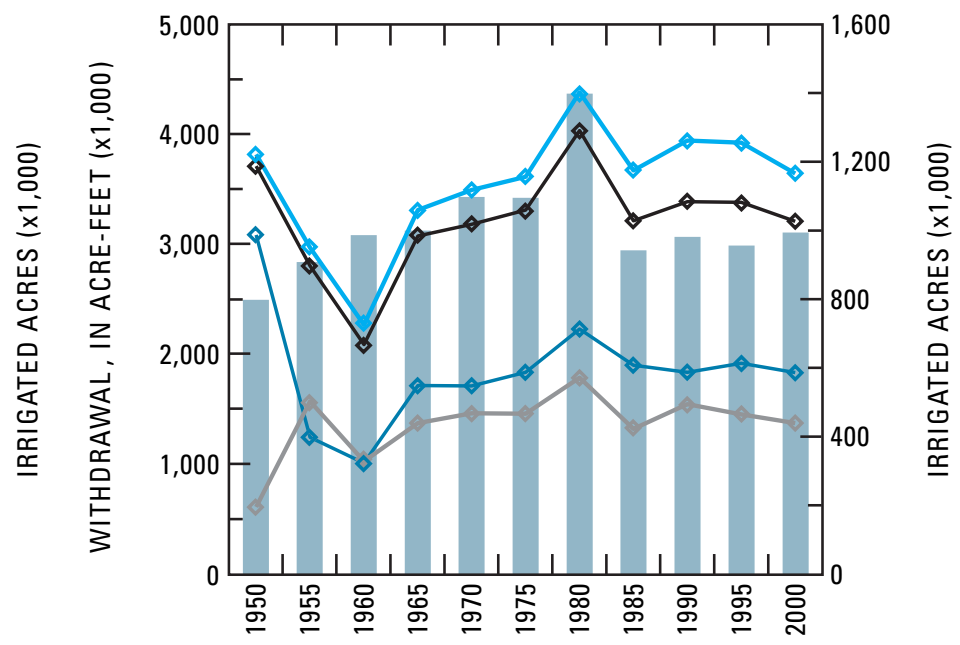

Figure 12. Total withdrawal, and ground-water, surface-water, and total withdrawal for agricultural uses, and irrigated acreage, 1950-2000; $A$, Arizona; $B$, California; $C$, Nevada; $D$, New Mexico; $E$, Utah. 
More than 80 percent of the water withdrawn in Arizona is for agriculture. The maximum annual withdrawal for agriculture in Arizona was 8.0 million acre-ft in 1980 (table 2 and fig. 12A). Agricultural withdrawals declined from 97 percent of the total withdrawal in 1950 to 80 percent in 2000 (fig. 10A). Ground water was the major source for agricultural use until 1980 when imported Colorado River water became available. In 1950, 62 percent of the water used for agriculture was ground water, and in 1995, 38 percent was ground water. Owing to the decline in surface-water withdrawal, perhaps because of the decline in irrigated acreage in the central part of the State, however, groundwater withdrawal was slightly greater than surface-water withdrawal in 2000. Irrigated acreage increased 17 percent between 1965 and 1975, when the maximum was reported, and decreased 30 percent between 1975 and 2000 (table 12).

The percentage of the water withdrawn in California for agriculture decreased from 92 percent to 82 percent between 1950 and 2000. This decreased percentage was the result of increased withdrawal for domestic use and more efficient irrigation methods. Surface water made up 56 percent of the withdrawal for agriculture in 1950 and 62 percent of the withdrawal for agriculture in 2000 (fig. 10B). Between 1965 and 2000, irrigated acreage increased 19 percent in California.

The estimated water withdrawal for agricultural use in Nevada increased 128 percent between 1950 and 1985 , when the maximum withdrawal for agriculture was reported. There was a 51-percent decline in withdrawal for agricultural use from 1985 to 1995, and a 28-percent increase in withdrawal for agriculture from 1995 to 2000 (fig. 12C). This trend corresponds with the trend of irrigated acreage. The amount of irrigated acreage in Nevada decreased 11 percent from 1965 to 2000 and 24 percent from 1975 to 2000 . Withdrawal for agricultural use was 95 percent of the total withdrawal in 1950 and 66 percent of the total withdrawal in 2000.

Surface water has been the major source of water for agricultural use in Nevada.

Withdrawal for agricultural use in New Mexico between 1950 and 2000 ranged from a low of 2.07 million acre-ft in 1960 to a high of 4.05 million acre-ft in 1980. The percentage of total withdrawal used for agriculture in New Mexico declined from 97 percent in 1950 to 88 percent in 2000 (table 2 and fig. 12D).

There was no net change in irrigated acreage in New Mexico between 1965 and 2000; however, irrigated acreage declined 28 percent from 1980 to 2000.

Withdrawal for agricultural use in Utah increased 25 percent from 1950 to 2000 , from 3.46 million acre- $\mathrm{ft}$ to 4.33 million acre-ft. Irrigated acreage increased 18 percent from 1965 to 2000 . Withdrawal for agricultural use, however, declined as a percentage of total withdrawals, following a trend similar to that of the four other States. The withdrawal for agricultural use in Utah accounted for 94 percent of the total withdrawal in 1950 and 83 percent of the total withdrawal in 2000.

The amount of withdrawal for agricultural use in the 58 counties within the Basin and Range Physiographic Province decreased 3 percent from 1985 to 2000 (table 8). Withdrawal for agricultural use declined from 86 percent of the total water withdrawn in 1985 to 81 percent in 2000 . The counties using the most water from 1985 to 2000 were Imperial County, Calif., and Maricopa and Yuma Counties, Ariz. One third of the total withdrawal for agricultural use and irrigated acreage in the Basin and Range Physiographic Province was in these counties.

Irrigated-acreage data shown by county in table 5 were reported by the USGS for the 5-year compilations and by the NASS for 1992 and 1997. There was an overall decline of 6 percent, 215,000 acres, between 1985 and 2000; irrigated acreage decreased in 24 counties, increased in 26 counties, and did not change in 8 counties in the Basin and Range Physiographic Province.

Irrigated-acreage data in table $\mathbf{1 3}$ show that since 1965 crop acreage declined in the Great Basin and Rio Grande water-resources regions, changed little in the lower Colorado water-resources region, and increased in the California water-resources region. There was an overall decline in the four regions of 3 percent. The large decline in the Rio Grande water-resources region occurred outside the Basin and Range Physiographic Province.

Crop-application rates (water withdrawn for irrigation of crops divided by irrigated acreage) from 1965 to 2000 ranged from 2.29 acre-ft/ac in Utah in 1975 to 6.18 acre-ft/ac in Arizona in 2000 (table 14 and fig. 13). Irrigated-acreage data published by the USGS were used to compute crop-application rates. The average for the eight data sets illustrates the differences and shows that, in all reporting years, more water was used per acre of irrigated land in Arizona than in each of the other four States. This difference could be due to several reasons, including differences in climate, conveyance losses, length of growing season, and type of crops grown. Most of the crops in Arizona have to be irrigated because most of the cropland is in the southern half of the State where the climate generally is arid. Climate can affect crop growing season, and the length of the season largely controls the amount of water used. Southern Arizona and southern California have longer growing seasons that are conducive to a wider variety of crop types and multiple crops per year, which result in greater water use. 
Table 13. Irrigated acreage in the lower Colorado, Great Basin, California, and Rio Grande water-resources regions, 1965-1995

[In thousands of acres]

\begin{tabular}{lrrrrrrr}
\hline \multicolumn{1}{c}{ Region } & $\mathbf{1 9 6 5}$ & $\mathbf{1 9 7 0}$ & $\mathbf{1 9 7 5}$ & $\mathbf{1 9 8 0}$ & $\mathbf{1 9 8 5}$ & $\mathbf{1 9 9 0}$ & $\mathbf{1 9 9 5}$ \\
\hline Lower Colorado & 1,200 & 1,300 & 1,500 & 1,400 & 1,474 & 1,527 & 1,260 \\
Great Basin & 1,800 & 1,900 & 2,400 & 1,900 & 1,904 & 1,940 & 1,610 \\
California & 8,800 & 9,000 & 9,300 & 10,000 & 9,750 & 9,610 & 9,540 \\
Rio Grande & 2,300 & 2,500 & 2,000 & 1,400 & 1,349 & 1,384 & 1,260 \\
& Total & 14,100 & 14,700 & 15,200 & 14,700 & 14,477 & 14,461 \\
\hline
\end{tabular}

Table 14. Crop-application rates in Arizona, California, Nevada, New Mexico, and Utah, 1965-2000

[In acre-feet per acre]

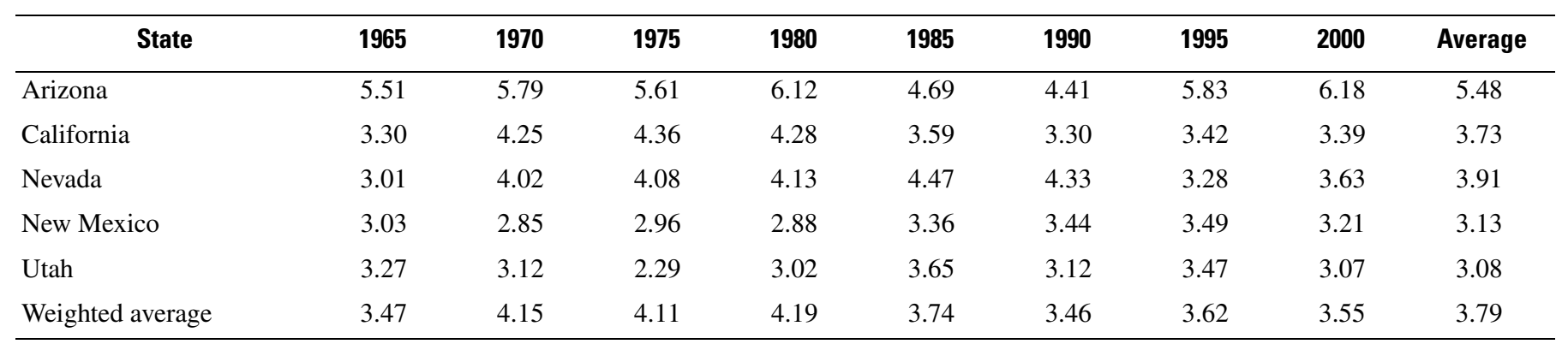

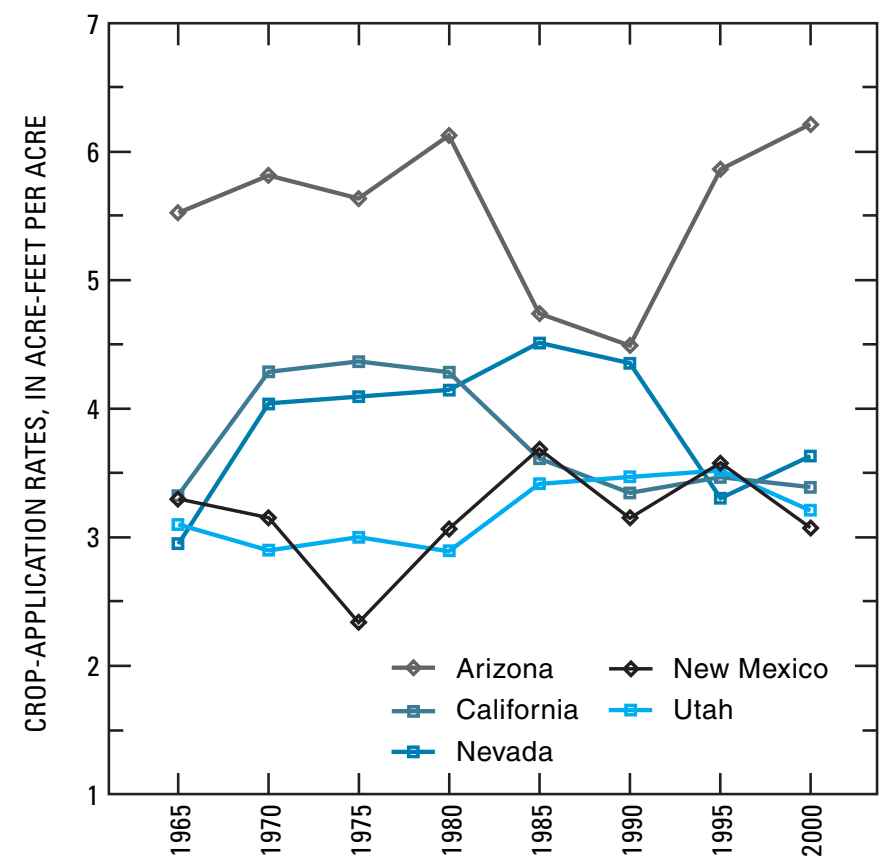

Figure 13. Crop-application rates in Arizona, California, Nevada, New Mexico, and Utah, 1965-2000. 


\section{Industrial Water Use}

Trends in industrial water use are difficult to identify because of the differences in the way that data are reported. Some industrial withdrawals are reported individually, and some are incorporated into the publicsupply withdrawals. Mining withdrawal estimates are not included in all of the 5-year compilations.

No discernible trend was identified for industrial use, which including withdrawals for mining increased almost 700 percent between 1950 and 1980 and decreased in the following years (table 2). In all the compilation reports, less than 4 percent of the total withdrawal in Arizona was for industrial use, except in 1990; less than 6 percent of the total withdrawal in California was for industrial use; and less than 7 percent of the total withdrawal in Nevada, New Mexico, and Utah was for industrial use, except in 1980 when in Utah it was almost 12 percent. Overall, withdrawal for industrial use in the five States was less than 5.5 percent of the total withdrawal. Industrial withdrawal was generally less than 5 percent of the total withdrawal in each water-resources region in the Basin and Range Physiographic Province, from 1965 to 1995. In the counties within the Basin and Range Physiographic Province, withdrawal for industrial use represented 2.6 percent of the total withdrawal in 1985 and 1.6 percent of the total withdrawal in 2000 (table 8).

\section{SUMMARY AND CONCLUSIONS}

Water-use data published by the USGS by State every 5 years from 1950 to 2000, by county from 1985 to 2000, and by major drainage region from 1965 to 1995 were the main source of information used to identify trends in water use in Arizona, California, New Mexico, Nevada, and Utah. Population and irrigated-acreage data from Federal, State, and local sources were also used to describe changes and identify trends.

Estimated water withdrawal in the five States for domestic, agricultural, and industrial uses increased 58 percent from 39.6 to 62.8 million acre-ft per year from 1950 to 2000. Withdrawal for domestic use increased 410 percent from about 2.0 to 10.2 million acre-ft per year. Total population in the five States increased 250 percent. From 1965 to 2000 withdrawal for agricultural use increased 14 percent and irrigated acreage increased 12 percent.
More than 80 percent of the total withdrawal in the five States is for irrigation of crops. From 1965 to 2000 withdrawal for agricultural use increased from 44.0 to 50.2 million acre-ft per year while the irrigated acreage increased from 12.6 to 14.1 million acres.

From 1960 to 2000 public supply per-capita use increased 51 percent in Arizona, 24 percent in New Mexico, and 3 percent in California. It decreased 2 percent in Nevada and 3 percent in Utah. Since 1985 the largest public supply per-capita use has been reported in Nevada.

Trends in the Southwest for all water-use categories are dominated by withdrawals in California, which are the largest in the country. From 1965 to 2000, irrigated acreage in California was at least twice as much as the combined irrigated acreage in Arizona, Nevada, New Mexico, and Utah. Withdrawal for agricultural use in California represents 62 percent of withdrawal for agricultural use in all five States in 1950 and 68 percent in 2000. Total estimated water withdrawal in California ranged from 25.0 million acre-ft in 1950 to 43.1 million acre- $\mathrm{ft}$ in 2000. The combined withdrawal in the other four States ranged from 14.6 million acre- $\mathrm{ft}$ to 19.7 million acre-ft for the same time period.

Crop-application rates between 1965 and 2000 ranged from 2.29 acre-ft per acre in Utah in 1975 to 6.18 acre-ft per acre in Arizona in 2000. More water is used per acre of irrigated land in Arizona than in the other four States. This difference could be attributed to differences in climate, conveyance losses, length of growing season, and type of crops grown.

Estimated ground-water withdrawal increased 62 percent and surface-water withdrawal increased 59 percent in all five States from 1950 to 2000. There were increases in ground-water withdrawal from 1950 to 2000 of 324 percent in Nevada, 147 percent in New Mexico, 208 percent in Utah, and 52 percent in California. Ground-water withdrawal decreased 15 percent in Arizona during this period.

The major identified trend was the proportional increase in withdrawal for domestic water use relative to withdrawal for agricultural water use. In 1950, 94 percent of the total water withdrawal was for agricultural use and 5 percent was for domestic use. Fifty years later, in 2000, 80 percent of the total water withdrawal was for agriculture and 16 percent of the total water withdrawal was for domestic use.

Distribution of available surface water, imposed water-conservation measures, legislated limits of ground-water withdrawal, and conjunctive use of water are being used in some areas where ground-water overdraft is occurring. In parts of the Southwest approaches to augment and sustain ground-water resources include recharge of unused surface water and treated wastewater. 


\section{SELECTED REFERENCES}

Anning, D.W., and Duet, N.R., 1994, Summary of groundwater conditions in Arizona, 1987-90, U.S. Geological Survey Open-File Report 94-476, 2 sheets, scale $1: 1,000,000$.

Arizona Crop and Livestock Reporting Service, 1966, Arizona agricultural statistics 1867-1965.

Arizona Department of Water Resources, 2003, Overview of the Arizona Groundwater Management Code, accessed June 2004 at URL http://www.water.az.gov/adwr/content/ Publications/files/gwmgtovw.pdf

Burden, C.B., Spangler, L.E., and others, 2000, Ground-water conditions in Utah, spring of 2000: Utah Department of Natural Resources Cooperative Investigations Report 41, $140 \mathrm{p}$.

California Department of Water Resources, 1980, Ground water basins in California-A report to the Legislature in response to Water Code Section 12924: California Department of Water Resources Bulletin 118-80, 73 p.

Coache, R.M., 2000, Las Vegas Valley water usage report, Clark County, Nevada: Nevada Division of Water Resources Report, 23 p.

Fenneman, N.M., 1931, Physiography of western United States: New York, McGraw-Hill, 534 p.

Harrill, J.R., and Worts, G.F., Jr., 1968, Estimated water use in Nevada, 1950-65: Nevada State Department of Conservation and Natural Resources Water Resources Information Series Report 7, 37 p.

Hitt, K.J., 2002, Physiographic divisions of the conterminous United States: U.S. Geological Survey, accessed January 2002 at URL http://water.usgs.gov/GIS/ metadata/usgswrd/physio.html

Horton, Gary, (no date), County hydrographic basins and areas: Nevada Division of Water Resources, accessed April 2001 at URL http://water.nv.gov/Water\%20planning/ cty-bsn/cty_map.htm

Hutson, S.S., Barber, N.L., Kenny, J.F., Linsey, K.S., Lumia, D.S., and Maupin, M.A., 2004, Estimated use of water in the United States in 2000: U.S. Geological Survey Circular 1268, accessed March 2004 at URL http://water.usgs.gov/ pubs/circ/2004/circ1268/

MacKichan, K.A., 1957, Estimated use of water in the United States, 1955: U.S. Geological Survey Circular 398, 18 p.

MacKichan, K.A., 1951, Estimated use of water in the United States, 1950: U.S. Geological Survey Circular 115, 13 p.

MacKichan, K.A., and Kammerer, J.C., 1961, Estimated use of water in the United States, 1960: U.S. Geological Survey Circular 456, 26 p.

Mann, W.B., IV, Solley, W.B., and Chase, E.B., 1983, Summary of water withdrawals in the United States, 1950-80: U.S. Geological Survey Open-File Report 83-207, 19 p.

Murray, C.R., 1968, Estimated use of water in the United States, 1965: U.S. Geological Survey Circular 556, 53 p.
Murray, C.R., and Reeves, E.B., 1977, Estimated use of water in the United States in 1975: U.S. Geological Survey Circular 765, $39 \mathrm{p}$.

Murray, C.R., and Reeves, E.B., 1972, Estimated use of water in the United States in 1970: U.S. Geological Survey Circular 556, $53 \mathrm{p}$.

Nevada Division of Water Planning, Department of Conservation and Natural Resources, 2000, Water Words Dictionary, accessed January 2002 at URL http://www.state.nv.us./cnr/ndwp/dict-1/wwords-h/pdf

Peltz-Lewis, L., 1998, Metadata for the digital dataset of hydrographic areas for the State of Nevada, 1974: U.S. Geological Survey digital data acquired 2000.

Planert, Michael, and Williams, J.S., 1995, Ground water atlas of the United States-Segment 1: California, Nevada: U.S. Geological Survey Hydrologic Investigations Atlas HA-370-B, 28 p.

Rush, F.E., 1968, Index of hydrographic areas in Nevada: U.S. Geological Survey, Water-Resources Information Series Report 6, 38 p.

Smales, T.J., and Harrill, J.R., 1971, Estimated water use in Nevada: Nevada Division of Water Resources, State of Nevada Water Planning Report 2, 32 p.

Solley, W.B., Barber N.L., and Merk, C.F., 1987, Water use in the United States-1980: U.S. Geological Survey WaterResources Investigations Report 86-4182, 1 plate.

Solley, C.R., Chase, E.B., and Mann, W.B., IV, 1983, Estimated use of water in the United States in 1980: U.S. Geological Survey Circular 1001, 56 p.

Solley, C.R., Merk, S.F., and Pierce, R.R., 1988, Estimated use of water in the United States in 1985: U.S. Geological Survey Circular 1004, 82 p.

Solley, C.R., Pierce, R.R., and Perlman, H. A., 1993, Estimated use of water in the United States in 1990: U.S. Geological Survey Circular 1081, 76 p.

Solley, C.R., Pierce, R.R., and Perlman, H. A., 1998, Estimated use of water in the United States in 1995: U.S. Geological Survey Circular 1200, $71 \mathrm{p}$.

Sorensen, E.F., 1982, Water use by categories in New Mexico counties and river basins, and irrigated acreage in 1980, New Mexico State Engineer Technical Report 44, 51 p.

Sorensen, E.F., 1977, Water use by categories in New Mexico counties and river basins, and irrigated and dry land cropland acreage in 1975, New Mexico State Engineer Technical Report 41, 34 p.

Tadayon, Saeid, Duet, N.R., Fisk, G.G., McCormack, H.F., Partin, C.K., Pope, G.L., and Rigas, P.D., 2001, Water resources data for Arizona, water year 2000: U.S. Geological Survey Water-Data Report AZ-00-1, 390 p.

Tadayon, Saeid, Duet, N.R., Fisk, G.G., McCormack, H.F., Partin, C.K., Pope, G.L., and Rigas, P.D., 2000, Water resources data for Arizona, water year 1999: U.S. Geological Survey Water-Data Report AZ-99-1, 370 p.

Tadayon, Saeid, Duet, N.R., Fisk, G.G., McCormack, H.F., Partin, C.K., Pope, G.L., and Rigas, P.D., 1999, Water 
resources data for Arizona, water year 1998: U.S. Geological Survey Water-Data Report AZ-98-1, 454 p.

Tadayon, Saeid, Duet, N.R., Fisk, G.G., McCormack, H.F., Pope, G.L., and Rigas, P.D., 1998, Water resources data for Arizona, water year 1997: U.S. Geological Survey WaterData Report AZ-97-1, 416 p.

Tucson Water, 2002, A comprehensive guide to clearwater 2001, accessed October 2003, at URL http://www.ci.tucson.az.us/water/water_resources/ clearwater/cw-2001.pdf

U.S. Census Bureau, 1997, Population projections, accessed February 2002 at URL http://www.census.gov/population/ www/projections/prpproj.html

U.S. Census Bureau, 2002, Index of population, accessed March 2002 at URL http://www.census.gov/population/ cencounts

U.S. Census Bureau, 2001, Population estimates-Historical annual time series of state population estimates and demographic components of change 1900 to 1990 total population estimates, accessed February 2002 at URL http://eire.census.gov/popest/archives/state/st_stts.php

U.S. Department of Agriculture, 1999, 1997 Census of agriculture-Volume 1: National, state, and county tables, accessed February 2002 at URL http://www.nass.usda.gov/ census/census97/volume1/vol1pubs.htm
U.S. Geological Survey, no date, Water use in the United States, accessed December 2003 at http://water.usgs.gov/ watuse/

U.S. Geological Survey, 2002, Middle Rio Grande Basin study, accessed January 2002 at http://rmmcweb.cr.usgs.gov/public/mrgb/mrgbhome.html

U.S. Geological Survey, 1990, National water summary 1987-Hydrologic events and water supply and use: U.S. Geological Survey Water-Supply Paper 2350, 553 p.

U.S. Geological Survey, 1985, National water summary 1984-Hydrologic events, selected water-quality trends, and ground-water resources: U.S. Geological Survey WaterSupply Paper 2275, 467 p.

Wilson, B.C., 1992, Water use by categories in New Mexico counties and river basins, and irrigated acreage in 1990: New Mexico State Engineer Technical Report 47, 141 p.

Wilson, B.C., 1986, Water use in New Mexico in 1985: New Mexico State Engineer Technical Report 46, 84 p.

Wilson, B.C., and Lucero, A.A., 1997, Water use by categories in New Mexico counties and river basins, and irrigated acreage in 1995: New Mexico State Engineer Technical Report 49, 149 p. 